\title{
Optimising Value from the Soft Re-use of Brownfield Sites
}

Bardos, Paul ${ }^{a, b} ;$ Jones, Sarah ${ }^{a}$; Stephenson, Ian $^{c}$; Menger, Pierre ${ }^{d}$; Beumer, Victor ${ }^{\mathrm{e}}$; Neonato, Francesca ${ }^{\mathrm{f}}$; Maring, Linda ${ }^{\mathrm{e}}$; Ferber, Uwe ${ }^{\mathrm{g}}$; Track, Thomas ${ }^{\mathrm{h}}$; Wendler, Katja ${ }^{\text {h }}$.

${ }^{a}{ }^{3}$ environmental technology UK Itd, H9 TOB1, University of Reading Whiteknights Campus, Reading, UK.paul@r3environmental.co.uk

${ }^{\mathrm{b} S}$ School of Environment and Technology, University of Brighton, Brighton, UK

'VERTASE-FLI, 19 Napier Court, Barlborough Links, Barlborough, Sheffield, S43 4PZ, UK. istephenson@vertasefli.co.uk

${ }^{\mathrm{d}}$ Tecnalia Research and Innovation Parque Tecnológico de Bizkaia, E-48160 Derio - Bizkaia, Spain.pierre.menger@tecnalia.com

eDeltares, Rotterdamseweg 185, Delft, 2629HD, The Netherlands, Victor.Beumer@deltares.nl and Linda.Maring@deltares.nl

fPN Studio, viale Monte Nero 12, 20135 Milan, Italy, info@pnstudio.net

${ }^{g}$ PROJEKTGRUPPE STADT + ENTWICKUNG, Ferber, Graumann und Partner, Stieglitzstrasse 84, 04229 Leipzig, Germany. Uwe_Ferber@projektstadt.de

hDECHEMA e.V., Theodor-Heuss-Allee 25, D-60486 Frankfurt a.M., Germany. track@dechema.de,wendler@dechema.de

\begin{abstract}
Soft re-use of brownfields describes intended temporary or final re-uses of brownfield sites which are not based on built constructions or infrastructure ('hard' re-use). Examples of soft re-uses include the creation of public green space. These are essentially uses where the soil is not sealed. Often the case for soft re-use of brownfields has not been easy to demonstrate in strictly financial terms. The purpose of this paper is to describe a value based approach to identify and optimise services provided by the restoration of brownfields to soft re-uses, on a permanent or interim basis. A 'Brownfield Opportunity Matrix' is suggested as means of identifying and discussing soft restoration opportunities. The use of 'sustainability linkages' is suggested as a means of understanding the sustainability of the services under consideration and providing a structure for the overall valuation of restoration work, for example as part of design or option appraisal processes, or to support the solicitation of interest in a project.
\end{abstract}

\section{Keywords}

Brownfields restoration; soft re-use of land; options appraisal; decision support; sustainability assessment; sustainability linkages; conceptual site models 


\section{Introduction}

Brownfields are a latent resource in sustainable land management. Brownfields are a symptom of changing times. While the presence of brownfields provides the necessary 'free' space for new developments within the urban environment - to meet evolving societal demands - brownfields often persist for longer than desirable. The recent European HOMBRE project ${ }^{1}$ argues that a clearer vision on what a brownfield site has to offer in responding to current and emerging societal challenges would help overcome such barriers (HOMBRE Consortium 2014).

'Circular land management' is a concept encapsulating sustainable and repeated use of development land: avoiding new brownfields, recycling existing brownfields and compensating the effects of land consumption (Ferber et al. 2011, HOMBRE Consortium 2014, van Arkel 2012). An important factor in circular land management is the reduction of both greenfield consumption and brownfield production. This can be achieved by maintaining land in productive use as far as possible, but where it falls out of use, to make sure its transition to a new land use is as rapid as possible. The return to use of land could be for built redevelopment, or for soft re-uses such as for urban green space. A possible intermediate scenario is that there may be an interim use, prior to longer term reestablishment into the land cycle (Holland et al. 2013, Seeds Consortium 2015) ${ }^{2}$.

'Hard' developments describe some form of building or infrastructure, and 'soft' re-use describes forms of use that do not involve substantial construction (Cundy et al. 2013). Soft land-use is where the land remains unsealed and the soil remains in biologically productive use, for example for agriculture, habitat, forestry, amenity or landscaping. The two scenarios are not mutually exclusive. Many development scenarios include both types of usage, for example landscaping in generally built up areas, or a visitor centre on a brownfield regenerated for public amenity. Hence EU policy on 'soil sealing' (EC 2012) can also be used as a context for distinguishing between hard and soft land usage. We suggest hard land usage is defined as re-use that predominantly contains built or paved development.

While historically there has been a preference for hard redevelopment of brownfield land (Ling et al. 2003), regeneration of brownfield areas for soft re-uses, such as green open space areas for amenity, is used for brownfield restoration in a number of countries including Germany, the United Kingdom and the Netherlands (Sarni 2009, Thornton et al. 2007, RESCUE 2005) 3 $^{3}$ There have been many successful examples of restoration to soft re-

\footnotetext{
${ }^{1}$ Holistic Management of Brownfield Regeneration, Co-funded by the European Union's Seventh programme for research, technological development and demonstration under grant agreement no. 265097. www.zerobrownfields.eu

${ }^{2}$ These processes of transition are broadly referred to as brownfield restoration or regeneration (CABERNET 2006; RESCUE 2005). This does not imply that the former use of the land has been restored, but that some additional level of functionality has been restored.

${ }^{3}$ Additional examples are in an on-line library produced by HOMBRE at http://dtvirt8.deltares.nl/bfnlibrary/htdocs/
} 
uses across Europe over the past 50 years. For example, garden exhibitions have been developed on brownfield sites including in Hamm, Germany and Glasgow, UK (Engel, 1988). However, the case for soft re-use restoration can be hard to demonstrate in strictly financial terms (Chilton et al. 2009). Where the direct economic benefits of restoration are not always readily identifiable as is the case when brownfields are to be regenerated into soft re-uses, it can be helpful for decision-makers to be fully aware of broader opportunities and benefits (including problems caused by disamenity) that can emerge from brownfield restoration, and how these opportunities and benefits translate into a more comprehensive understanding of overall value, as described in Section 6.

The purpose of this paper is to describe a value-based approach for optimising services from restoration of brownfields for soft re-use on a permanent or interim basis developed by the HOMBRE project (Beumer et al. 2014, Menger et al. 2013). The value of restoration underpins the rationale for any public or private investment in brownfield restoration. We believe that in some cases this value is too narrowly costed, and opportunities for improving an overall proposition of value are being missed. Synergies between improvements in environmental, economic and social services could enhance the overall value of brownfield restoration and so help create expanded opportunities for brownfield re-use. This paper sets out the components of a common framework, shown in Figure 1, for different stakeholders to propose, estimate and discuss overall value from the restoration of brownfields into soft re-use (i.e. non-sealed soil based redevelopment of land). Applying this framework would provide a structure for the overall valuation of restoration work, for example as part of design or option appraisal processes, or to support the solicitation of interest in a project.

The key components of this framework, shown in Figure 1, include:

- Several conceptual ideas: 'project services', 'overall value' and 'sustainability linkages';

- A tool for maximising the scope of potential opportunities from brownfield reuse (the 'Brownfield Opportunity Matrix' (BOM);

- Approaches for understanding sustainability and overall value; and

- A process to support decision-making and design in planning soft re-uses for brownfield land based on sustainability and a shared understanding of overall value.

The process has four broad stages: (1) making use of the BOM to identify a range of project services from soft re-use and their potential value; (2) building a conceptual site model (CSM) using 'sustainability linkages' taking both the direct and wider effects of these services into account; (3) using the CSM to provide a framework for sustainability assessment and cost effectiveness assessment; (4) using these assessments to provide a shared understanding of overall value, and also private understandings of monetised value that are individual to particular stakeholders (especially potential investors), but linked to the generally shared opinion of cost effectiveness.

This paper cites extensively from grey literature as much of the state of the art in brownfields restoration has been developed in the practitioner domain. 


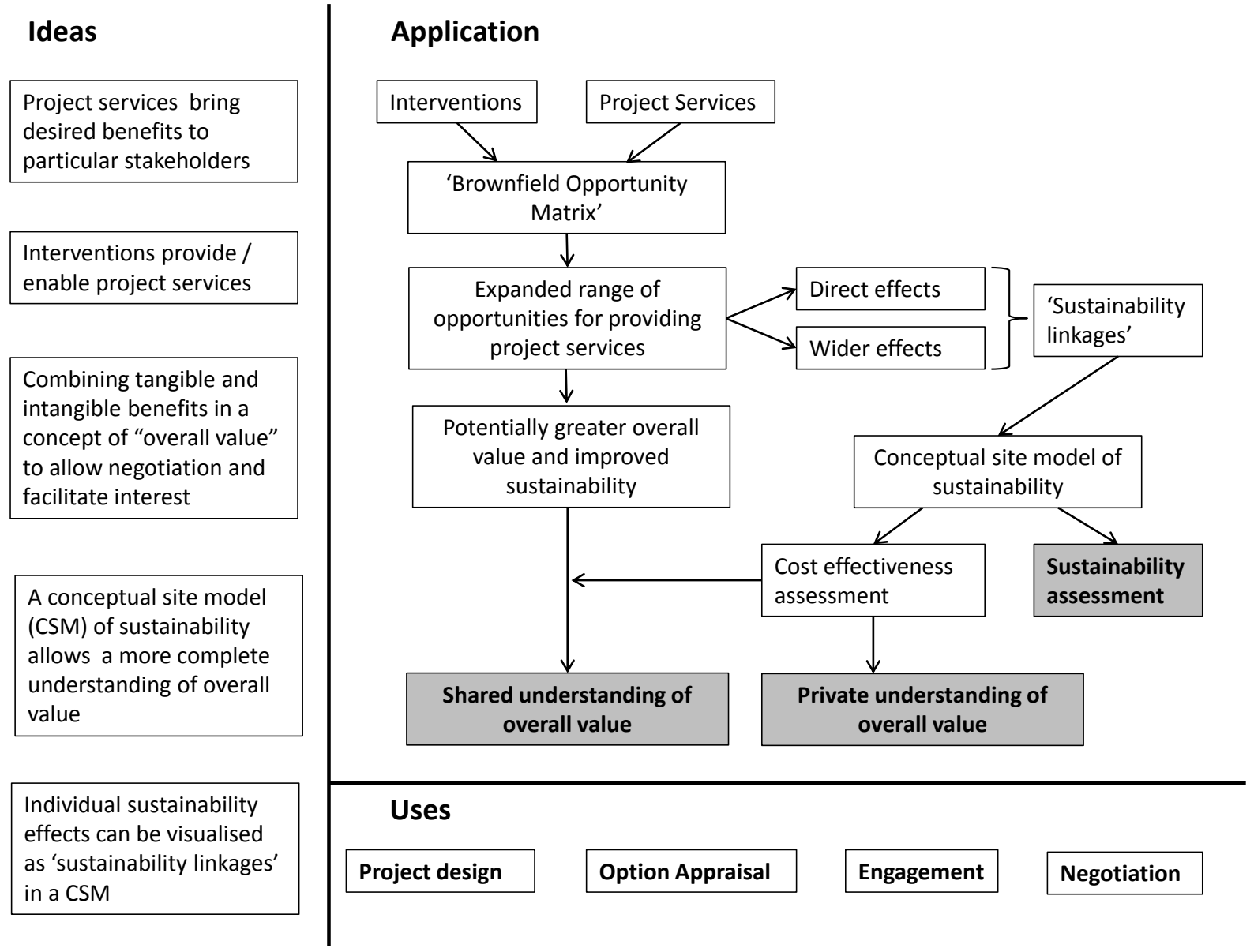

Figure 1. Proposed framework for optimising value from the soft re-use of brownfield sites

\section{Rationale}

The value of land is dependent on the type of land use and the demand for that land use (Syms and Weber 2003). Markets discount the value of degraded land, such as brownfield land, based on assumptions relating to the likely direct and indirect costs of rehabilitation. The effect of these constraints on a site's value can persist even after the completion of remediation (Bartke 2011). Brownfield sites with land contamination problems are likely to be particularly disadvantaged because of their higher liability burden. Liabilities relate to potential losses, typically monetary, but other types of loss are possible, for example reputational (NICOLE 2011). However, a change in land use can substantially increase land value, for example, a change from an industrial use to a use for retail and housing. The effect of land use change on value is dependent on location and market rates for similar land uses in the vicinity. For a brownfield site, this change in value may be sufficient to pay for site restoration and also generate useful revenue from a future land sale. Therefore, development of such land usually proceeds under the influence of market forces (Lee and Coffin 2005).

The European CABERNET project (Ferber et al. 2006, Tang and Nathanail 2012) categorised brownfield sites as ' $A$ ', ' $B$ ' or ' $C$ ', as shown in Figure 2 where:

- A Sites are economically viable and the development projects are driven by private funding. These have tended to be for building redevelopments (i.e. hard re-use). 
- B Sites are on the borderline of profitability. These projects tend to be funded through public-private co-operation or partnerships.

- C Sites are not in a condition where restoration can be profitable. Their restoration relies on mainly public sector or municipality driven projects. Public funding or specific legislative instruments (e.g. tax incentives) are required to stimulate restoration of these sites.

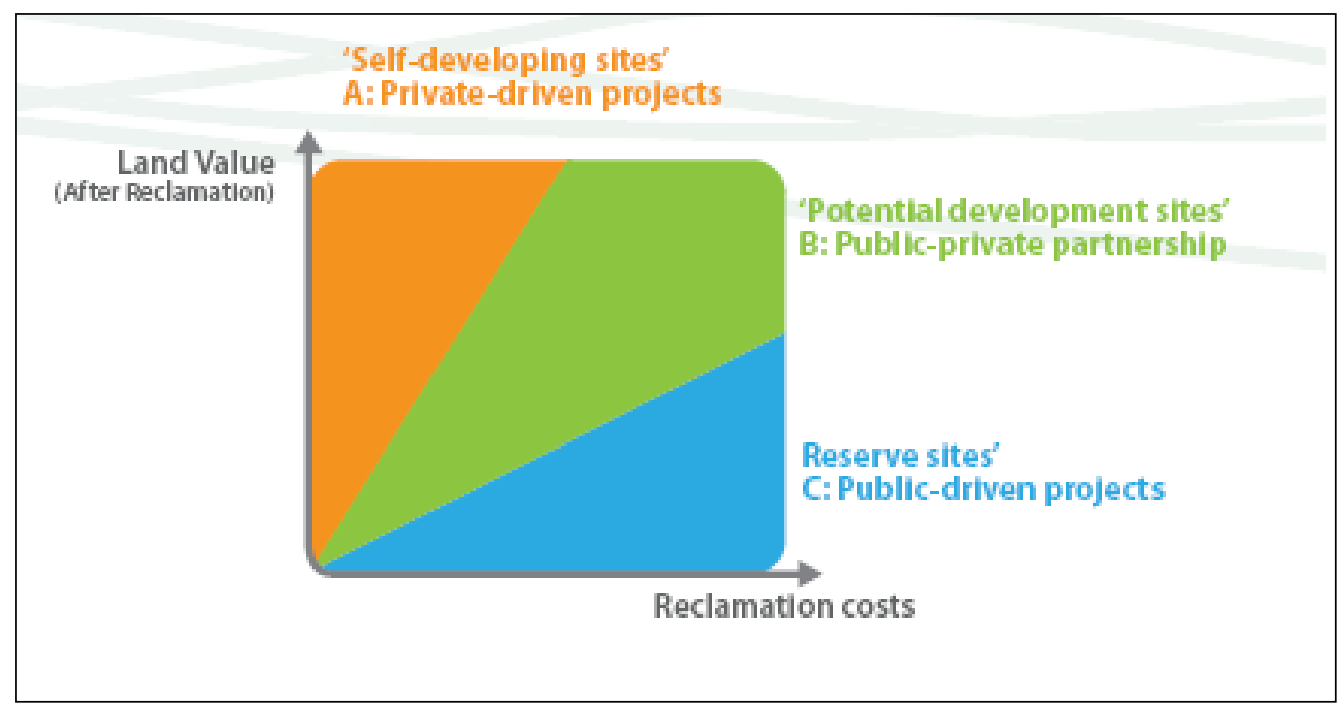

Figure 2: CABERNET ABC Model for brownfield Sites (taken from CABERNET 2006).

Away from economically active areas, the profitability for less advantaged brownfield sites may be borderline, or conventional restoration may proceed only at a loss (Lee and Coffin 2005). In these situations, soft-re-uses could create opportunities for longer term and lower input restoration, where restoration for hard re-use is simply not feasible (Ling et al. 2003; US EPA 2010; VALUE Project 2012). However, the case for considering soft re-use of brownfields depends on demonstrating value sufficient to justify the investment required to achieve the re-use. Multiple benefits may underpin this value (see Table 1), and these benefits can accrue to different stakeholders (as described later in this paper). Hence a shared concept of value is needed to support the necessary investment, given the difficulties in agreeing direct financial valuations (as developed in Section 6).

There is a broad range of possible soft re-use strategies that can provide a range of benefits, for example, for amenity or on-site energy production, either as a permanent or interim measure. Soft re-uses are mostly mediated by plants, whether as part of the landscape of an open space, or for providing benefits of an urban 'green lung' or for a productive purpose such as growing biomass (Adelaja et al. 2010; Haase, 2008; Mathey et al. 2015; Sinett et al. 2015). The growth of plants and hence the viability of soft re-uses is dependent on a suitable level of soil functionality (Cundy et al. 2013). An ecologically informed approach can produce significant cost-benefits by building on the natural restoration often found on derelict sites (Handley 1996). 
Table 1: Potential overarching benefits of brownfields redevelopment (Summarised from Paull 2008)

\begin{tabular}{|c|c|}
\hline Environmental & $\begin{array}{l}\text { - } \text { Reduced use of Greenfield sites } \\
\text { - Air quality improvements (from reduced transportation } \\
\text { needs to more distant Greenfield locations) } \\
\text { - Reduced energy consumption and greenhouse gas } \\
\text { production (from reduced transportation needs to more } \\
\text { distant Greenfield locations) } \\
\text { - Water quality benefits } \\
\text { - Environmental benefits (for example reduced negative } \\
\text { ecosystem impacts) }\end{array}$ \\
\hline Economic & $\begin{array}{l}\text { - } \text { Site value } \\
\text { - Neighbouring property values } \\
\text { - Employment and investment benefits } \\
\text { - Leverage of additional investment } \\
\text { - Leverage of additional employment } \\
\text { - Improvement in local property values } \\
\text { - Improvement of local taxation revenues } \\
\text { - Avoidance of Greenfield infrastructure requirements / } \\
\text { agglomeration benefits (e.g. greater urban density) }\end{array}$ \\
\hline Social & $\begin{array}{l}\text { - Reduced threat to public health } \\
\text { - } \text { Reduced traffic (from reduced transportation needs to more } \\
\text { distant Greenfield locations) } \\
\text { - Amenity benefits such as improved appearance } \\
\text { - Health benefits }\end{array}$ \\
\hline
\end{tabular}

Some examples of the potential beneficial outcomes from different types of soft re-use projects are as follows.

- In many European countries densely urbanised areas might benefit from more open space. Open spaces in urban areas can provide multiple services (Chiesura 2004, Bolund and Hunhammer, 1999), including human health benefits (Alcock et al. 2014). Brownfield sites have great potential to help provide for this. Rehabilitation of brownfield in general can foster public health benefits in the local community. Where this is associated with public access to greenspace there may be significant additional benefits to public health and wellbeing (Bambra et al. 2014, Morrison et al. 2014, Forest Research 2010.).

- A renaissance of new forms of urban gardening, community gardens and urban farming increases the demand for, and feasibility of, adapting brownfields for green uses. (DVRPC 2008, Taylor and Lovell 2012).

- Soft re-uses are an option for renewable energy generation and biofuel stocks (Lord et al. 2008).

- Soft re-uses can include green infrastructure that offers several benefits for communities (leisure, culture or ecosystem services). For example, mitigation of heat 
island effects and improvement of urban comfort, if designed appropriately and at strategic locations (Doick and Hutchings 2013, Chiesura 2004, Bolund et al. 1999).

- Green infrastructure with trees can help improve air quality in urban areas by filtering and retaining air particles and contaminants generated by traffic and industry (Forest Research 2010; Nowak et al. 2006). In the urban context, trees are considered to provide the most significant effect on decreasing the urban heat island effect (Skelhorn et al 2014). Green infrastructure can also help create habitat for migrating birds and other species in urban and peri-urban areas (Natural England 2009, Benedict and McMahon 2006).

- The cumulative impacts of soft re-uses can contribute not only to local but also more global challenges e.g. (as green infrastructure) adaptation and mitigation of climate change impacts (Natural England 2009).

- The presence of green infrastructure has been linked to significant positive effects on surrounding property values and capacity to raise local taxation (Greenspace Alliance 2010). Part of the financial equation for public sector funders may be improved taxation through brownfield restoration benefits to the local economy, such as job creation or increased tax take from increased land values (BenDor et al. 2011).

It is also salient to note that brownfields (or portions of brownfields) are also increasingly being considered for soft re-use even within economically active areas, for example to provide urban green space such as parks or even community farms (Cowan et al. 2005, DVRPC 2008). This is particularly important for urban areas where there may be competing interests for land for example between housing and green infrastructure, when opportunities for synergy should be explored (CABE 2005).

\section{Project services as a means of exploring and improving overall benefits and hence value from the restoration of brownfields for soft re-uses,}

Restoration of a brownfield site for a new re-use is a designed process, where a number of interventions (e.g. remediation, soil improvement) are deployed to achieve a particular set of beneficial outcomes of interest to different stakeholders. We have stripped this down to its component parts as follows. Interventions are made to provide services which create benefits for particular stakeholders, but which will also be accompanied by wider effects on environment, economy and society, as summarised in Figure 3 . The sustainability of a restoration project is therefore the combination of the benefits of the services it delivers and the wider effects of the interventions employed to deliver these services, as shown in Figure 4. The value of a project, in terms of what will stimulate stakeholders to invest in it is driven by the services the project will deliver, tempered by level of acceptability of their wider effects. Our working hypothesis has been that examining sustainability more closely might increase the range of services of interest to different stakeholders, and so improve both the overall value and attractiveness of a planned brownfield restoration project.

HOMBRE adopted a pragmatic and functional description to better understand the linkage between restoration project benefits and a project's value to different stakeholders. We use the term 'project service' to express the benefits obtained by specific beneficiaries (i.e. stakeholders). There are three components for a project service to occur. These are: 
- An intervention of some kind (such as the examples listed in Table 2, below)

- One or more planned benefits as outcomes of the intervention

- One or more beneficiaries for these outcomes

These services are delivered or enabled through interventions, i.e. the implementation of processes during the restoration of brownfields and/or the subsequent maintenance of specific land uses. These interventions and the services they provide are specific outcomes of a restoration project design process.

The purpose of considering 'project services' is to be able to clearly describe restoration project outcomes in a way that can specifically address the desired benefits of different stakeholder interests, and so more clearly demonstrate a value proposition for investment to the different stakeholders with potential interest in a project, for example, at planning and proposal stages. Sufficient value leverages a brownfield restoration, by providing benefits that make the investment in restoration worthwhile to specific constituencies or beneficiaries who will support it. This may manifest as a direct financial input, for example via grant funding; or taxation advantages, via levies on wider development initiatives to support local community infrastructure (e.g., DCLG 2011).

\section{Inputs}

(may also

be outputs

from other

processes)

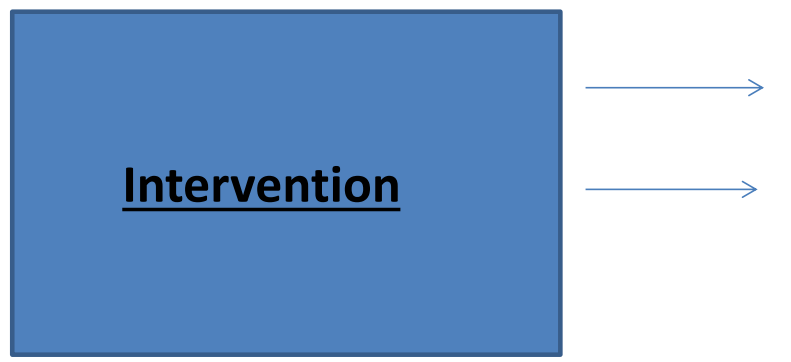

\section{Wider Effects \\ May be positive or negative}

\section{Desired Service}

(i.e. "designed in" positive effects): may be: a change in a "fixed asset" like a land area with improved soil or landscape; may be a product like biomass or cleaned water; may be a facility like carbon storage or capacity for waste recyclate use; may be amenity such as open space or leisure.

\section{Benefits for} particular stakeholders

Figure 3 HOMBRE's simple model of the delivery of benefits from brownfield restoration (C) r3 environmental technology Itd 2015, reproduced by permission

Table 3 provides a set of examples of possible project services from brownfield restoration for soft reuse. We accept that both the interventions in Table 2 and the project services listed in Table 3 could be categorised and collated in different ways. The important points 
are that the scope of both are wide ranging, and they can be structured in a way that makes their role more obvious to different stakeholders and more readily translatable to processes such as design , options appraisal and valuation.

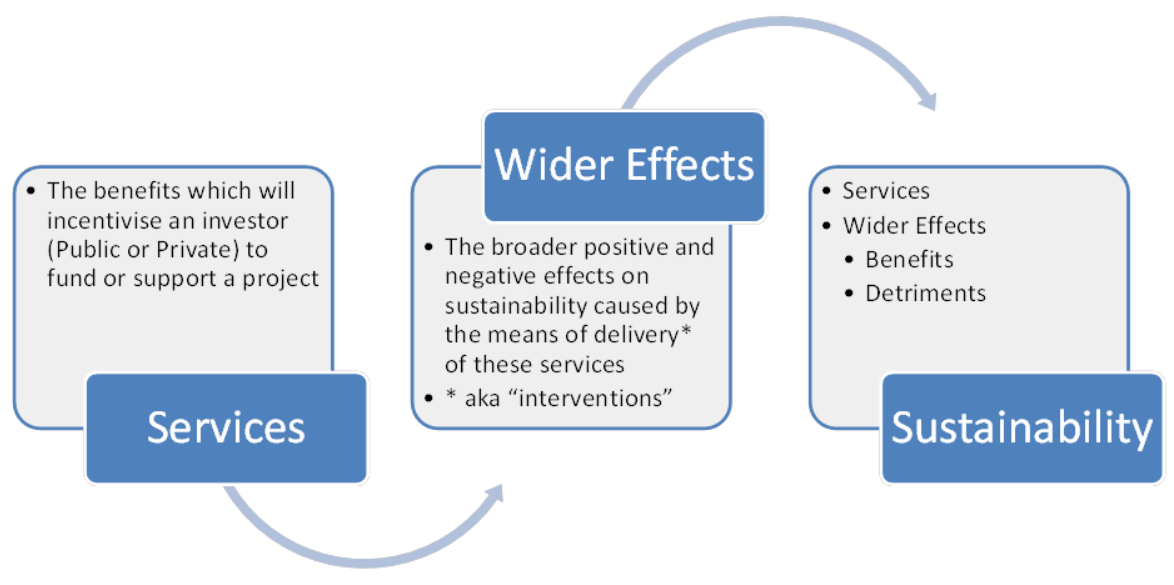

Figure 4: Services and sustainability (C) r3 environmental technology ltd 2015, reproduced by permission

Table 2: Interventions that might be used in brownfields restoration for soft end uses

\begin{tabular}{|c|c|c|}
\hline $\begin{array}{l}\text { Broad } \\
\text { intervention }\end{array}$ & Variants & Examples \\
\hline \multirow{8}{*}{$\begin{array}{l}\text { Gentle } \\
\text { remediation } \\
\text { options }\end{array}$} & \multirow{5}{*}{$\begin{array}{l}\text { Phyto- } \\
\text { remediation }\end{array}$} & Phyto-extraction \\
\hline & & Phyto-stabilisation \\
\hline & & Phyto-containment \\
\hline & & Phyto-filtration \\
\hline & & Phyto-degradation/stimulation \\
\hline & \multirow{2}{*}{$\begin{array}{l}\text { Amendment } \\
\text { addition }\end{array}$} & In situ stabilisation - char/biochar \\
\hline & & In situ stabilisation - slags, compost etc \\
\hline & $\begin{array}{l}\text { Natural } \\
\text { attenuation of } \\
\text { groundwater }\end{array}$ & Monitored natural attenuation of groundwater \\
\hline \multirow{2}{*}{$\begin{array}{l}\text { Conventional } \\
\text { remediation }\end{array}$} & \multirow[t]{2}{*}{ Ex situ } & Ex situ bioremediation \\
\hline & & Soil washing \\
\hline
\end{tabular}




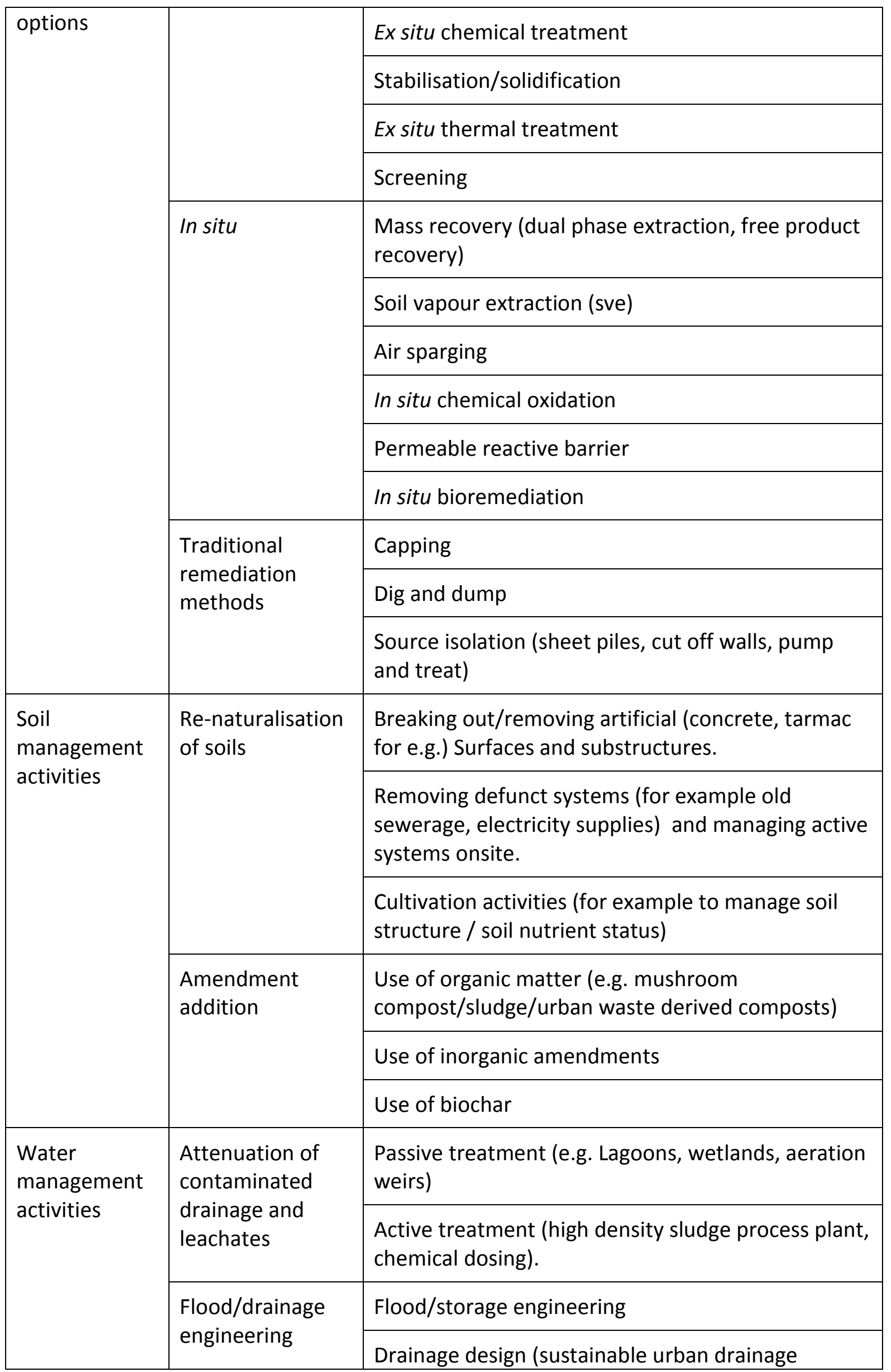




\begin{tabular}{|c|c|c|}
\hline & & systems (suds) for e.g.) \\
\hline & & $\begin{array}{l}\text { Maintenance and improvement of water ways } \\
\text { onsite }\end{array}$ \\
\hline \multirow{3}{*}{$\begin{array}{l}\text { Implementing } \\
\text { green } \\
\text { infrastructure }\end{array}$} & \multirow{3}{*}{$\begin{array}{l}\text { Green } \\
\text { infrastructure }\end{array}$} & Ecological engineering \\
\hline & & Biodiversity and environmental management \\
\hline & & Conservation \\
\hline \multirow[t]{7}{*}{ Renewables } & \multirow{3}{*}{$\begin{array}{l}\text { Producing } \\
\text { renewable } \\
\text { feedstocks }\end{array}$} & Biofeedstock/biomass \\
\hline & & Topsoil substitute production \\
\hline & & On site recycling/valorisation \\
\hline & \multirow{4}{*}{$\begin{array}{l}\text { Energy } \\
\text { generation }\end{array}$} & Geothermal/ground source \\
\hline & & $\begin{array}{l}\text { Biomass energy creation (e.g. Wood, biofuel, } \\
\text { biogas) }\end{array}$ \\
\hline & & $\begin{array}{l}\text { Photo-voltaic/solar panels for power generation } \\
\text { and heating water }\end{array}$ \\
\hline & & Wind turbines \\
\hline \multirow{7}{*}{$\begin{array}{l}\text { Sustainable } \\
\text { land planning } \\
\text { and } \\
\text { development }\end{array}$} & \multirow{5}{*}{$\begin{array}{l}\text { Development of } \\
\text { amenities }\end{array}$} & Landscape planning and development \\
\hline & & Leisure design, development and management \\
\hline & & Educational facility development \\
\hline & & $\begin{array}{l}\text { Provision of facilities such as: fencing, paths, paving } \\
\text { and other small building works }\end{array}$ \\
\hline & & Provision of visitor facilities \\
\hline & \multirow{2}{*}{$\begin{array}{l}\text { Strategic planning } \\
\text { of land use over } \\
\text { time }\end{array}$} & Promotion of green/soft reuse \\
\hline & & Integration of hard and soft developments \\
\hline
\end{tabular}

The exact choice of project services and the most efficient way in which they can be delivered determines the usefulness and hence the value of a restoration project. Project design will likely need to consider a range of synergies, trade-offs and potential net losses (Haase et al. 2012; Rodriguez et al. 2006) in the context of ecosystem services appraisal, as shown in Figure 5. The same concepts can apply to project services. Synergy describes a situation where a process or combination of processes on a site delivers several useful services in a way that provides a net improvement for the financial feasibility and sustainability of a project. An example might be linking 'gentle' remediation and biomass 
cultivation, or some other form of intervention such as green infrastructure. Other examples of synergies that might be possible in brownfields restoration for a soft re-use include:

- Combining use on on-site and off-site biomass to gain economies of scale.

- Using biochar as carbon sink (climate change) and soil improvement for plant growth (Ahmad et al. 2014).

- Green infrastructures as means to improve air quality, water storage, biodiversity landscape and urban climate comfort (Natural England 2009).

Trade-offs describe situations where one service must be balanced against another service because while there are advantages in including both services in a project, there is some interference between them. For example, a site might need to consider a trade-off between biomass production and open space green infrastructure to provide for both ongoing income to help manage a site and providing amenity for a local community.

A net loss is where combining two project services would effectively result in a net loss. An example might be where there is both a demand for an improved landscape to support value uplift, for example for an adjacent built development platform; and also a demand for renewable energy for that platform envisaged as photovoltaic generation from the same landscape. In many cases these demands might be seen as being in clear conflict, although of course this would strongly depend on opinions, and could perhaps be mitigated by an alternative form of renewable energy supply.

Table 3 Examples of possible project services from brownfield restoration for soft reuse

\begin{tabular}{|c|c|c|}
\hline $\begin{array}{l}\text { Broad } \\
\text { category of } \\
\text { service }\end{array}$ & Subcategories & Examples \\
\hline \multirow{4}{*}{$\begin{array}{l}\text { Risk mitigation } \\
\text { of } \\
\text { contaminated } \\
\text { land and } \\
\text { groundwater }\end{array}$} & \multirow[t]{2}{*}{ Biosphere } & Human health protection \\
\hline & & Protection of ecology \\
\hline & \multirow{2}{*}{$\begin{array}{l}\text { Water resources } \\
\text { (hydrosphere) }\end{array}$} & Surface water treatment (e.g. acid mine drainage) \\
\hline & & Groundwater treatment and protection \\
\hline \multirow[t]{6}{*}{$\begin{array}{l}\text { Soil } \\
\text { improvement }\end{array}$} & \multirow[t]{3}{*}{ Fertility } & $\begin{array}{l}\text { Managing nutrient and micronutrient availability to } \\
\text { support vegetation }\end{array}$ \\
\hline & & Improving soil biological functionality \\
\hline & & $\begin{array}{l}\text { Improving soil condition to support desired } \\
\text { plant/crop }\end{array}$ \\
\hline & \multirow[t]{3}{*}{ Soil structure } & Improve soil resilience \\
\hline & & Providing vegetative cover \\
\hline & & Mitigation measures for soil erosion and landsliding \\
\hline \multirow{3}{*}{$\begin{array}{l}\text { Water } \\
\text { resource } \\
\text { improvement }\end{array}$} & \multirow{3}{*}{$\begin{array}{l}\text { Water resource } \\
\text { efficiency and } \\
\text { quality }\end{array}$} & Supply of (treated) water for on-site uses \\
\hline & & Provision of potable water resource \\
\hline & & Improved quality of surface water \\
\hline
\end{tabular}




\begin{tabular}{|c|c|c|}
\hline & Subcategories & Examples \\
\hline & \multirow{2}{*}{$\begin{array}{l}\text { Flood and } \\
\text { capacity } \\
\text { management }\end{array}$} & Retention of runoff / surface water storage \\
\hline & & $\begin{array}{l}\text { Flood mitigation (incorporating mitigation of severe } \\
\text { weather events) }\end{array}$ \\
\hline & \multirow[t]{2}{*}{$\begin{array}{l}\text { Rehabilitation of } \\
\text { water }\end{array}$} & $\begin{array}{l}\text { Rain / drainage water (including sustainable } \\
\text { drainage) }\end{array}$ \\
\hline & & $\begin{array}{l}\text { Leachate treatment and reuse (landfill, acid mine, } \\
\text { etc.) }\end{array}$ \\
\hline \multirow{5}{*}{$\begin{array}{l}\text { Provision of } \\
\text { green } \\
\text { infrastructure }\end{array}$} & \multirow{2}{*}{$\begin{array}{l}\text { Enhancing } \\
\text { ecosystem } \\
\text { services }\end{array}$} & $\begin{array}{l}\text { Protection of habitat and biodiversity (where } \\
\text { existing and for protected sites) }\end{array}$ \\
\hline & & Developing new habitat and increasing biodiversity \\
\hline & \multirow{3}{*}{$\begin{array}{l}\text { Enhancing local } \\
\text { environment }\end{array}$} & Improve urban soundscapes and air quality \\
\hline & & Limiting visual intrusion by landscaping \\
\hline & & $\begin{array}{l}\text { Urban climate management (such as mitigation of } \\
\text { urban heat island effect) }\end{array}$ \\
\hline \multirow{8}{*}{$\begin{array}{l}\text { Mitigation of } \\
\text { human } \\
\text { induced } \\
\text { climate } \\
\text { change (global } \\
\text { warming) }\end{array}$} & \multirow{3}{*}{$\begin{array}{l}\text { Renewable } \\
\text { energy } \\
\text { generation }\end{array}$} & Energy for on-site use \\
\hline & & Energy for off-site use \\
\hline & & Supply to an integrated energy mix \\
\hline & \multirow{3}{*}{$\begin{array}{l}\text { Renewable } \\
\text { material } \\
\text { generation }\end{array}$} & Biofeedstocks (for biofuel/gas/plastics) \\
\hline & & Re-use of organics \\
\hline & & Re-use of aggregates \\
\hline & \multirow{2}{*}{$\begin{array}{l}\text { Greenhouse gas } \\
\text { mitigation }\end{array}$} & Reduced greenhouse gas emissions \\
\hline & & Carbon sequestration \\
\hline \multirow{14}{*}{$\begin{array}{l}\text { Socio- } \\
\text { economic } \\
\text { benefits }\end{array}$} & \multirow[t]{10}{*}{ Amenity } & Open space \\
\hline & & Leisure \\
\hline & & Education \\
\hline & & Improved health and wellbeing \\
\hline & & Access (footpaths, cycle routes) \\
\hline & & Tourism \\
\hline & & Community centre \\
\hline & & Views and viewpoints \\
\hline & & Framing built developments \\
\hline & & Grazing \\
\hline & \multirow[t]{4}{*}{ Economic assets } & Job generation \\
\hline & & Land value recovery over time \\
\hline & & Area value uplift \\
\hline & & Interim land management \\
\hline
\end{tabular}


Providing a wide range of project services in association with brownfield restoration can both improve value for projects that would go ahead anyway and enhance value sufficiently to allow projects to regenerate brownfields which would otherwise remain stalled and effectively out of the land use cycle. The most favourable combination is a synergy, but trade-offs are also likely to be important. A situation to be avoided is where seeking two project services would effectively result in a net loss.

Differences in stakeholder interests will have an impact on analysis of synergies, trade-offs and losses because relative values may be very different for different stakeholder groups for any particular project service or wider impact.

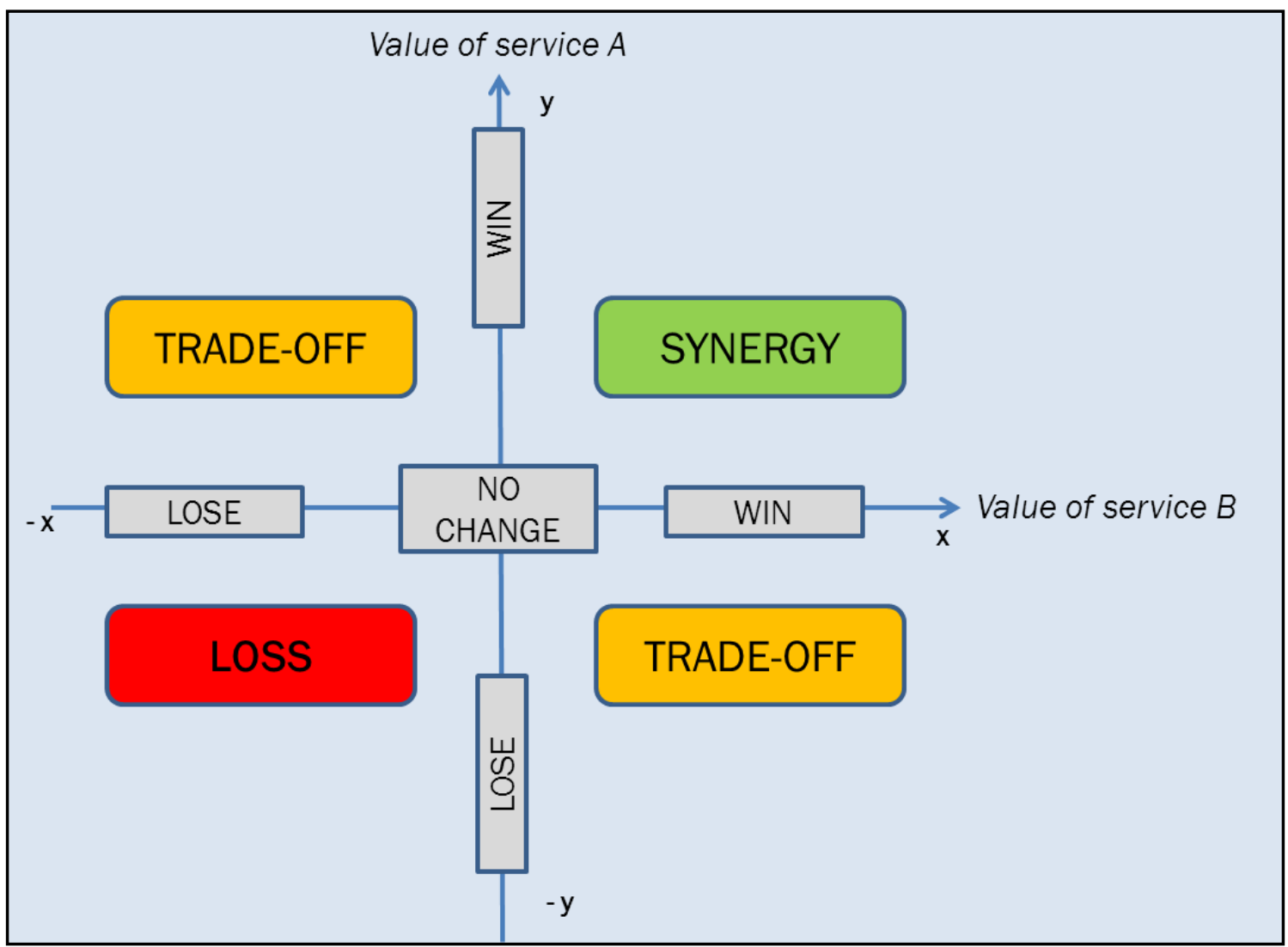

Figure 5: Schematic representation of interactions of project services resulting from brownfield regeneration and soft re-use of (adapted from Haase et al. 2012)

\section{The relationship between ecosystem services and 'project services'}

Almost every resource that humankind uses on a day-to-day basis relies directly or indirectly on nature. The benefits that humans derive from nature are known as ecosystem services (World Resources Institute 2003). Ecosystem services can be divided into four categories: provisioning services, regulating services, habitat or supporting services, and cultural services. Assessment of ecosystem services informs environmental planning and policy (TEEB 2011A and B). Assessment operates from a project level (creation or investment in green infrastructure) up to local/regional level, and seeks to consider both the direct and indirect values created by ecosystem services (van der Meulen et al. 2011). 
In this paper 'project services' have been described from the perspective of informing stakeholders clearly what benefits a brownfield restoration project might deliver to facilitate engagement and support for a project. The ecosystem services cascade model of the use of ecosystem services describes ecosystem services are a fundamental property of an ecological structure, which has ecological processes or functions. It is these processes or functions which deliver goods or services of benefit to Society (Luederitz et al. 2015). Nonetheless, there is a close alignment between project services and the categories of ecosystem services.

Examples of project services that can be directly mapped to ecosystem services (TEEB 2011A and $B$ ) include the following:

- Provisioning services fit with project services such as:

- Biomass production for feedstocks or energy

- Regulating ecosystem services fit with project services such as:

- Acid mine drainage management

- Mitigation of pollution (i.e. from site contaminants) by biological processes in situ

- Waste re-use and recycling for urban settlements (e.g. creating opportunities for beneficial re-use of composts, digestates or aggregate)

- Habitat or supporting services fit with project services such as:

- Nature conservation (for example sites of special scientific interest) on brownfields

○ Biodiversity management

- Cultural ecosystem services link with project services such as:

- Benefits to human health and social cohesion from the provision of open space

- Landscaping, turf etc. for leisure based land uses

However, project services and ecosystem services are not fully aligned for three reasons:

- Not all benefits or improvements in value achievable from brownfield restoration find a direct translation within the scope of ecosystem services, for example the generation of recyclate (such as steel, aggregate) during a brownfield restoration is a result of human activity rather than an ecosystem service.

- $\quad$ Some project services are consequential economic benefits. These include the recovery of land values for the site and surrounding areas, the facilitation of wider developments, improvements in balance sheets, benefits for intangible values for the project participants such as reputational benefits and removal of reliance on primary and also less secure resources (for energy and raw materials). These consequential benefits tend to have a major bearing on the economic viability of brownfields restoration, and the investment case that can be made for it.

- The ecosystem service concept describes a 'steady state' of provision. However, benefits from brownfield restoration accrue both from the process and the outcome of restoration. Here process describes the operational phase of the interventions being applied which may be temporary in nature (for example recovery of aggregates from a soil washing plant). Outcome describes the re-use of the site, which may require ongoing interventions, i.e. public park, urban forest, biomass production etc.

Ecosystem services are an important part of the delivery of benefits from brownfields restoration for sot re-uses, and detailed suggestions have been made of the most effective 
way of taking them into account during project planning (Atkinson et al. 2014; Doick et al. 2009). Project services provide a wider palette of services to interest stakeholders encompassing both benefits delivered by ecosystem services; those delivered by humanmade non-eco-system processes or they may be consequential. Ecosystem services and 'project services', as described in this paper, are a complementary considerations

\section{The Brownfield Opportunity Matrix}

One of the outputs of the EU HOMBRE project is a decision support tool called the 'Brownfield Opportunity Matrix' or 'BOM'4. The BOM was designed to help developers and others involved in brownfields to identify what services they can get from soft reuse interventions for their site, how these interact and what the initial default design considerations might be. The BOM is a simple Excel based screening tool that essentially maps the services that might add value to a redevelopment project against the interventions that can deliver those services, as described in Tables 2 and 3 . It would be used initially at an early stage in the framework for optimising value from the soft re-use of brownfield sites set out in Figure 1; but could also form part of iterative processes of restoration project design and option appraisal (Beumer et al. 2014)

The BOM maps the prospective range of opportunities that might be realised by a brownfield redevelopment project and the project's consequent sources of value. This mapping identifies where there are strong synergies between interventions and services, and also the occurrences of antagonism. Wherever a particular intervention delivers a service, this interaction creates an opportunity to add value. The matrix describes the kinds of value that each opportunity might generate, in terms of:

- Revenue generation of direct financial value: for example capital value uplifts, or income opportunities for example from renewable energy or leisure

- (Wider) Economic value - tangibles: e.g. increase of land and property values in the area providing benefits to the local community and also the investor.

- (Wider) Economic value - intangibles: benefits that are not readily agreed as monetisable by all stakeholders.

In addition, as part of its function is to engage different groups of stakeholders, it highlights:

- Natural Capital: including (but not limited to) providing green infrastructure, improvement of the local climate, improvement of water resources and mitigation of contamination (protecting and enhancing local ecosystem/environment).

- Cultural Capital: from improving the social environment (e.g. by improving the aesthetics of an area and/or creating a sense of place/belonging for e.g.) and can be a direct result of an increase in natural capital.

In terms of the overall valuation approach to cost effectiveness assessment suggested by HOMBRE (see Section 6) natural and cultural capital would be included as components of direct financial value or wider economic value

\footnotetext{
${ }^{4}$ Downloadable from: http://bfn.deltares.nl and www.zerobrownfields.eu/Displaynews.aspx? ID=568, accessed November 2015
} 
The BOM has been produced in two variants: a full-scale 'informational' version and an outline 'simple' version, to give different levels of detail (Figure 6 and Figure 7, below).The simple matrix is an 'outline' of the informational version and provides only mapping of services with interventions, with links to examples of particular opportunities. This version of the matrix is intended for use by those who do not necessarily have a background in remediation and/or sustainability, for example, during exploratory discussions with a range of stakeholders. In the informational matrix, for each opportunity there is a hyperlink to additional information, including at least one case study. There is also supporting information to describe the various services and interventions listed in the matrix. This version of the matrix is intended for use by those requiring more detailed information for example, for initial project master-planning, information signposting to more detailed information sources, validation of stakeholder choices and identification of additional challenges and opportunities as part of an iterative design and discussion process (Beumer et al. 2014).

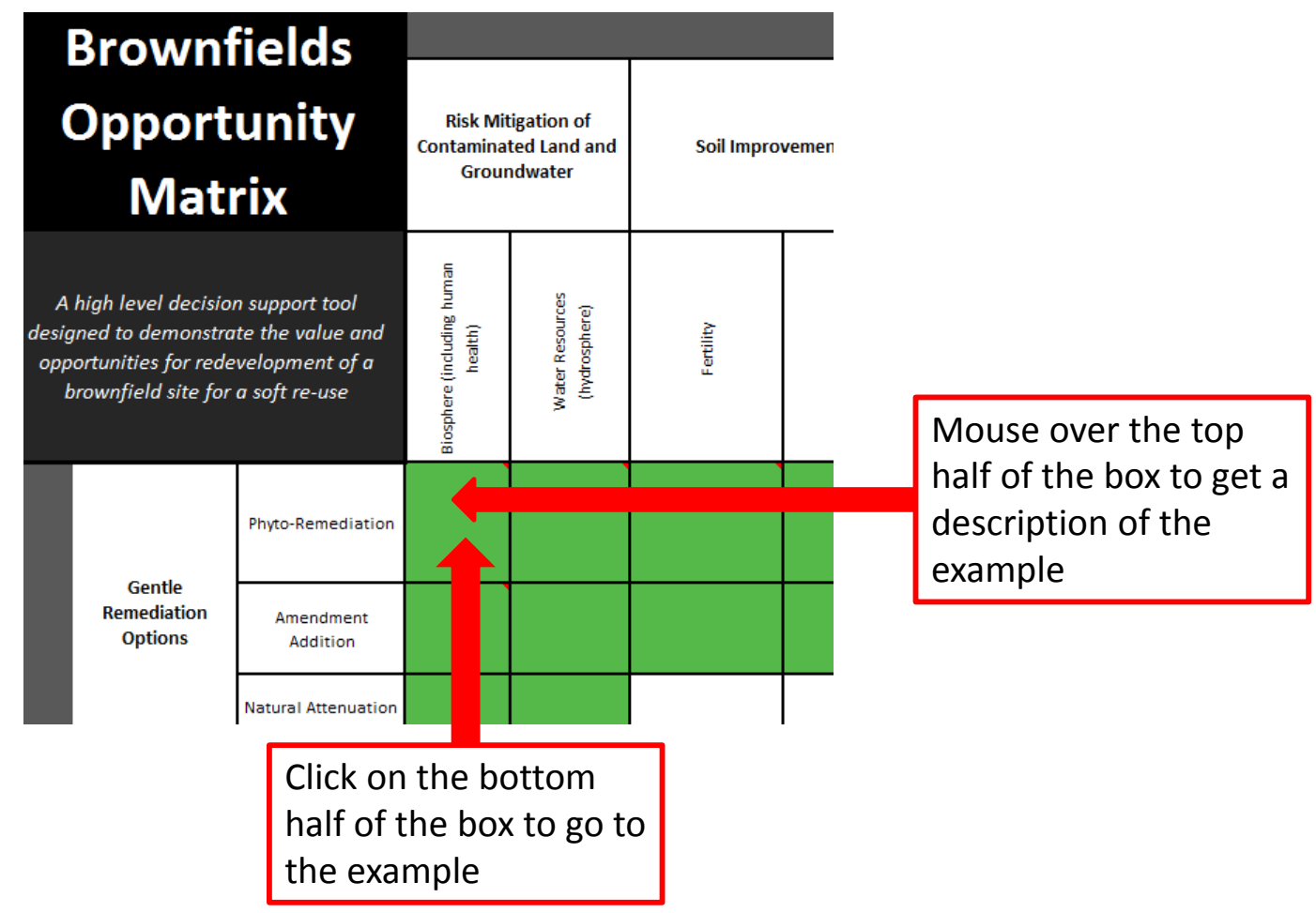

Figure 6: Simple Brownfield Opportunity Matrix Variant (c) r3 environmental technology Itd 2015, reproduced by permission 


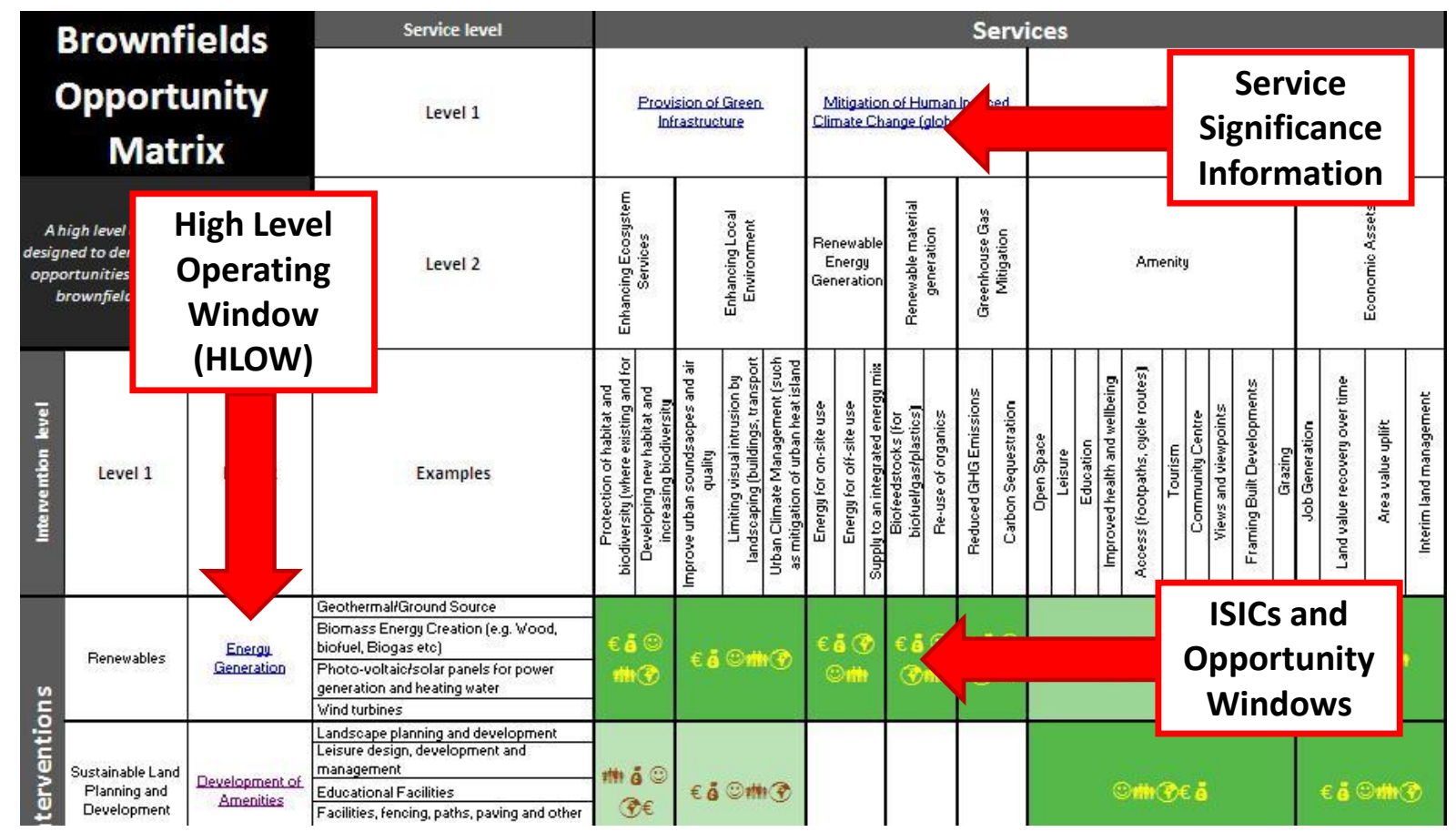

Figure 7: Informational Brownfield Opportunity Matrix variant (note ISIC=Intervention/Service Interaction Cells (C) $r 3$ environmental technology Itd 2015, reproduced by permission

\section{6. 'Overall value': valuing costs and benefits from restoration for soft re-uses}

For a brownfield restoration to take place, actors have to be incentivised to invest in it. This incentivisation will most likely depend on predicting a greater value of the restoration outcome than the value of the investment made. However, this incentivisation may result from a wider concept of value than solely financial returns. Instead an overall value may be the incentivisation for public, private and/or charitable investment in brownfields restoration, which might include improvements in wider environmental, social or economic value, as well as improvements in direct financial value.

There is an emerging body of opinion that value is a wider concept than direct financial return alone, and this view has a wider resonance for brownfield restoration. These ideas are consistent with the rapidly developing concepts of sustainable remediation and sustainable restoration (Bardos 2014, RESCUE 2005, CABERNET 2006). Sustainable brownfield restoration has been defined as 'the management, the rehabilitation and return to beneficial use of the brownfield land resource base in such a manner as to ensure the attainment and continue satisfaction of human needs for present and future generations in environmentally non-degrading, economically viable, institutionally robust and social acceptable ways' (RESCUE 2005, CABERNET 2006).

Sustainability assessment (or appraisal) is a process of gaining an understanding of possible outcomes across all three elements (environmental, social, and economic) of sustainable development. Sustainability management is the discipline of integrating sustainability assessment in decision making (Bardos et al. 2011). Sustainability assessment is increasingly 
being used in support of decision making for brownfield restoration projects (RESCUE 2005, CL:AIRE 2006, 2007a,2007b, REVIT Consortium 2007). This reflects the increasing recognition of the wider potential benefits of brownfield restoration to sustainable development. While there is no internationally accepted prescriptive standard technique for assessing sustainability for restoration or remediation, broad principles have been identified for both remediation and restoration contexts (Rizzo et al. IN PREP) and a descriptive standard for sustainable remediation is under development within ISO as ISO/DIS 18504 (ISO 2015). Inevitably, trade-offs must occur when designing a method for sustainability assessment (Bartke and Schwarze 2015). Stakeholder involvement is an important part of sustainability assessment for restoration and remediation projects to provide more robust and acceptable assessments (Cundy et al. 2013, Pediaditi et al. 2005, in accordance with the Bellagio principles (Hardi and Zdan 1997).

However, while sustainability assessment provides a framework for understanding overall outcomes in a holistic way, it also has major weaknesses in terms of being a convincing basis for financial investment decision making as there is no clear outcome in terms of measurable economic value and ultimately, the investments that facilitate re-use of a brownfield site for soft re-use are financial. Conventionally, cost-benefit assessment is used as the rationale for investment decisions.

Cost-benefit assessment describes a process of comparing the likely costs of a project with its benefits and is a form of economic valuation. Where this assessment is based on conversion to strictly monetary terms for comparison it is described as cost-benefit assessment - CBA (Commonwealth of Australia 2006). CBA has been widely applied to contaminated site management decision making (Bardos 2008a, 2008b). CBA can be seen by some stakeholders as a way of producing a very clear-cut decision about overall benefit (Brouwer and van Ek 2004; ELD Initiative 2015).

On the other hand, CBA also has weaknesses and needs be used with caution, in particular for understanding outcomes for brownfields restoration for soft re-use, which may intersect a broad range of stakeholders. CBA does not (may be cannot) readily value all considerations of interest to stakeholders in a way that is universally understood or accepted, or indeed may not even recognise or include them (Cellini and Kee 2010). It is important that the people in organisations commissioning CBA are able to fully consider the subtleties and nuances inherent in the technique (Atkinson and Mourato 2008). Attempts have been made to carry out economic valuation for green space infrastructure development (e.g. Vandermeulen et al. 2011). Nevertheless, the limitations of formal CBA mean that some stakeholders, in particular campaigning organisations, may be highly resistant to the use of cost benefit analysis as a justification for decision making $\mathrm{n}$ principle (Ackerman 2008).

Since sustainability assessment, with an appropriate level of stakeholder engagement, can identify both tangible and intangible value considerations and rank choices accordingly; combining sustainability assessment with CBA could provide a method of assessing overall value in a way that has broad acceptability. The combined approach would be a form of cost effectiveness assessment using more than a single metric. This is not a novel approach, as long ago as 1995 the Dutch 'REC' tool for remediation option appraisal proposed three 
metrics: risk reduction, cost and 'environmental merit' (Beinat et al. 1998, Cappuyns and Kessen 2012), and there are several examples of combinations of cost effectiveness and multi criteria approaches (e.g. Cellini and Kee 2010; Döberl et al. 2013; Harbottle et al. 2008 a and b; Pizzol et al. 2016).

HOMBRE's concept of 'overall value' recognises that the same brownfield restoration may have a range of components of value, which differ both in scope and worth between interested parties or stakeholders (developer, local community, local government etc.). 'Overall value' incorporates both direct financial returns and wider tangible and intangible forms of value:

1. Direct financial value - which can be included in a conventional cost benefit assessment

2. Wider effects which are economically tangible and so can also be included in a conventional cost benefit assessment

3. Wider effects which are economically intangible (e.g. because not all stakeholders agree them to be monetisable) and so need to be aggregated and considered in a nonmonetised way.

Determination of overall value recognises that for each stakeholder a project will perceive a direct financial value and a wider value, reflecting their interests and type of participation in the project. This wider value may include components that have tangible or intangible economic value. A tangible value is quantifiable and related to an identifiable source or asset, for example, appreciation of surrounding property values. An intangible value is not directly quantifiable but relates to an identifiable source. Examples include losses in productivity, customer goodwill or drops in employee morale.

Overall value therefore reflects a compromise between the different stakeholders involved in a restoration project that while they might not be able to agree a formal monetised costbenefit analysis; they can agree that a proportion of services and externalities (wider effects) can be monetised, either as a direct financial value from a desired project service, or an economically tangible wider effect. Other sources of value (or cost) cannot be monetised in a way that is collectively agreeable to all the stakeholders involved, need to be appraised by some other means. Hence, while a shared CBA not be possible, an overall cost effectiveness assessment becomes possible on a collective basis.

Some stakeholders may have an absolute requirement for a particular valuation approach, for example, in the UK HM Treasury (2011) requires a specific valuation approach for Social Cost Benefit Analysis. This approach would not necessarily be acceptable to all stakeholder, e.g. an NGO (Ackermann 2008). Use of the overall value concept allows individual stakeholders to conduct their own private cost benefit analyses and connect it to the collectively agreed CEA.

Additionally, individual stakeholders may monetise intangibles for other organisational purposes based on their own precedents, for example, to investigate consequential benefits. Identification of intangible values in the context of sustainable development may 
be translatable into goodwill ${ }^{5}$ for businesses involved in restoration projects, such as reduced project risks and improved reputational value, which may improve the shareholder value of a company. This consideration may be important to those making a financial investment.

Valuation of intangible business assets is increasingly important as they underpin medium to longer term financial performance (Riley et al. 2011). For instance:

- A public agency may provide financial support to facilitate a brownfield restoration project with limited or zero effective financial return. However, the wider value of the project to the agency might include tangible benefits such as an improved local taxation base, and intangible benefits such as meeting a particular policy objective. For example, improved public health and well-being - brownfield land can be associated with poorer public health in the nearby area (Bambra et al. 2014).

- A developer would most likely expect a significant direct financial return on its investment, for example in terms of higher property value; but may also benefit from the project wider value. Its tangible benefits might include securing adjacent development land. Its intangible benefits might include improved reputational value.

The key stages in such an approach to determining overall value would therefore be:

1. A shared conceptual model for services and overall sustainability which provides a framework for understanding components of value (taking into account any costs) linked to financial returns, tangible and intangible value. Where a component cannot be readily agreeable as monetisable, it should be assigned as an 'intangible'.

2. The use of monetisation for direct financial returns from services and economically tangible components of wider value.

3. The use of an agreed form of multi-criteria analysis to combine considerations that cannot be monetised and provide a scoring of the interventions being considered.

4. Individual stakeholders may use valuations (such as goodwill) for providing broader monetisation of overall value, taking into account that this may not represent a shared opinion across all stakeholders involved in the project design and decision process.

This approach is in line with previously published valuation concepts. Defra (2012) reviews options for the economic assessment of remediation benefits for contaminated land. It proposes a concept called 'Total Economic Value'. This is comprised of two components: 'use' values related to the direct benefits of bringing land back into use for built or soft development; and 'non-use values' which are benefits derived from knowledge that a particular resource is maintained. Plant et al. (2015) attempt to describe types of value and how to combine different stakeholder perceptions of value in a system they call value-based land remediation. They distinguish:

1. Monetary value - material or monetary worth (e.g. increased property value);

2. Importance or worth - the regard in which something is held (e.g. cultural heritage);

3. Individual and organisational values - principles or standards of behaviour.

\footnotetext{
${ }^{5}$ Goodwill describes identifiable intangible assets acquired in a business transaction, typically the excess of the purchase price of a company over its book value. www.investopedia.com/terms/g/goodwill.asp Accessed July 2015
} 
They suggest that a more open consideration of opinions about value can improve the delivery of wider benefits.

Careful consideration of project services can be used as a basis both to understand financial benefits and, in conjunction with the wider effects of the interventions used to deliver them, a basis for the sustainability assessment. The sustainability assessment process may itself identify additional opportunities for project services. Using sustainability linkages (described in Section 7) to understand both a conceptual model for sustainability for the site not only provides a framework but adds a transparent framework for stakeholders to agree and document which effects can fall into the different categories of overall value:

- Direct financial value - direct monetary returns generated

- Tangible wider value - a quantifiable cost or financial gain related to an identifiable source or asset.

- Intangible wider value - value that is not directly quantifiable.

\section{Conceptual site models for sustainability}

Sustainability assessment is site specific and subjective. It depends on the inclusion of a wide range of considerations across different stakeholder perspectives (Bleicher and Gross 2010), and as discussed in Section 6. A conceptual model for sustainability can be very helpful by providing a comprehensive yet simple and transparent means of recording and understanding the sustainability issues surrounding the site and project. The idea of conceptual models for sustainability is already established in various sectors (e.g. Caeiro et al. 2010; Todorov and Marinova 2009). What is new in this proposal is the idea of building a conceptual site model (CSM) from specific individual 'sustainability linkages' in a way that exactly maps sustainability outcomes from cause to "receptor", allowing duplications to be identified and allowing the effects of project services to be combined in a single sustainability model along with any wider impacts (positive or negative) from their implementation. Individual linkages can also be assigned to the different components of 'overall value', i.e. direct financial returns, economically tangible wider value and intangible forms of wider value. Using sustainability linkages to draw up a conceptual site model of sustainability therefore supports a robust connection between sustainability assessment and cost-benefit assessment and supports estimation of the overall value of the project.

A sustainability linkage is proposed as having three connected components, as shown in Figure 8. All three components need to be connected for a sustainability effect to exist:

- A source (pressure or change): this describes a factor that might cause an effect, for example, the emission of $\mathrm{CO}_{2}$ or an increase in road traffic.

- A mechanism: this describes how harm or benefit might be brought to a particular receptor. For example, the emission of PM10 particulate matter in road traffic exhaust; an increase in congestion that causes delay to other road users; or an increased risk of accident from additional vehicle movements.

- A receptor: the constituent of economy, environment or society that could be affected by a change / pressure via a mechanism. For example, human beings (i.e. society), via PM10 particulates or increased risk of accidents; or local economy, via increased costs of delivery arising from congestion. 
This concept is based on similar ideas of linkages from contaminated land risk assessment and liability assessment (Nathanail and Bardos 2004; NICOLE 2011). These sustainability linkages would be used as tools for crystallising available and relevant information for 'sustainability'. The purpose is to help stakeholders recognise, prioritise and deal with the management of the sustainability for a particular site and project, and better understand overall value. i.e. if a sustainability linkage exists there is a potential set of connections that can have an effect on sustainability (positive or negative) which can be precisely described. This precision is particularly useful for prioritisation and development of a CSM of sustainability.
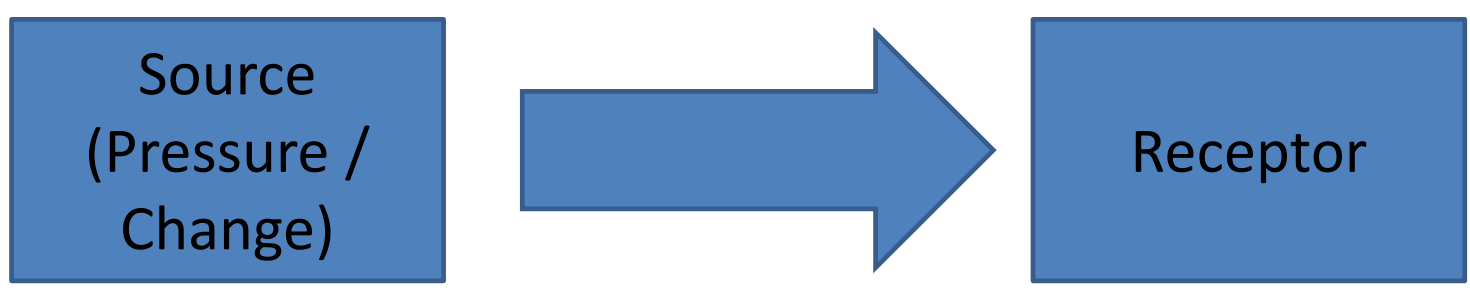

(e.g. emission of $\mathrm{CO} 2$, creation of dust, creation of recyclate)

$$
\begin{aligned}
& \text { e.g. global warming, } \\
& \text { aerial deposition, } \\
& \text { avoidance of use of } \\
& \text { virgin soil }
\end{aligned}
$$

\author{
e.g. atmosphere, local \\ housing and cars, soil \\ resources
}

Figure 8: Components of a Sustainability Linkage

Sustainability linkages may be temporary or longer term. This is an important distinction and which linkages to consider as relevant in a project depends on how 'sustainability' is being perceived by stakeholders. For example, a strictly intergenerational approach may disregard temporary effects, whereas these temporary effects may be very important to stakeholders living within the vicinity of a project. This is an example of boundary setting which is a key initial step in sustainability assessment. Typically, boundary setting must consider system and life cycle boundaries, as well as considerations of time and distance (Bardos et al. 2011). 'Scope' of linkages also needs to be identified. Scope describes the range of pressures which are being considered. There are a number of sources of check-lists that can be used to identify possible sustainability pressures, or to benchmark stakeholder led suggestions, to ensure suitable breadth, for example the SURF-UK guidance (CL:AIRE 2011). The overarching Categories from the SuRF-UK guidance can be found in Table 4, below. Each overarching category can then be broken down into a series of more specific considerations. Each factor can then be considered and an informed opinion should be made regarding its relevance. An explicit reason must be given for excluding a pressure, in order to provide the most rigorous sustainability assessment process possible.

Combinations of sustainability linkages can be shown in a network diagram to provide a more simplified representation than tables of linkages, analogous to the use of network diagrams to show source-pathway-receptor linkages in risk assessment (Nathanail and 
Bardos 2004). Using sustainability linkages clarifies which pressures are affecting which receptors and how this effect is occurring. Sustainability linkages can then be represented in a conceptual site model and prioritised analogous to pollutant linkages for risk assessment. Indeed pollutant linkages may form a component of an overall sustainability model. Sustainability linkages can have pressures, mechanisms or receptors in common. Network diagrams allow duplications to be identified and discarded. The simple rule of thumb is that each pressure, mechanism and receptor is (as far as possible) only shown once in the network diagram, and arrows are used to show how they are interconnected by sustainability linkages. Hence the conceptual site model for sustainability can be used for the same purposes of communication between stakeholders and improving transparency of decision making as is now regular practice for conceptual site models used in risk assessment and management.

Table 4: Overarching Categories from SuRF-UK (CL:AIRE 2011)

\begin{tabular}{|l|l|l|}
\hline Environment & Social & Economic \\
\hline Emissions to Air & Human health and safety & $\begin{array}{l}\text { Direct economic costs and } \\
\text { benefits }\end{array}$ \\
\hline Soil and ground conditions & Ethics and equity & $\begin{array}{l}\text { Indirect economic costs and } \\
\text { benefits }\end{array}$ \\
\hline $\begin{array}{l}\text { Groundwater and surface } \\
\text { water }\end{array}$ & Neighbourhoods and locality & $\begin{array}{l}\text { Employment } \\
\text { employment capital }\end{array}$ \\
\hline Ecology & $\begin{array}{l}\text { Communities and } \\
\text { community involvement }\end{array}$ & $\begin{array}{l}\text { Induced economic costs and } \\
\text { benefits }\end{array}$ \\
\hline Natural resources and waste & Uncertainty and evidence & $\begin{array}{l}\text { Project lifespan and } \\
\text { flexibility }\end{array}$ \\
\hline
\end{tabular}

Figure 8 shows an example network diagram developed for a preliminary options appraisal at the Parys Mountain site in Anglesey, North Wales (taken from Bardos and Menger 2013). The site has been affected by contamination resulting from a long history of copper mining. The risk management problem at the site is one of wind blow of copper laden dusts from former settlement ponds during dry periods to adjacent housing. An additional project service required is to support the reestablishment of heather vegetation on the settlement ponds. A range of options were considered to provide risk management and support revegetation. A spreadsheet of linkages identified as significant was compiled. The network diagram was simply constructed by repeatedly sorting the spreadsheet of linkages so that common pressures, mechanisms and receptors could be identified in a preliminary assessment.

Any conceptual model will likely develop iteratively along the phases of decision making and project implementation. This development is analogous to the use of conceptual site models for risk assessment and risk management decision making. Iterative development of a conceptual model is likely to involve reviewing initial conditions, identifying the most pressing sustainability concerns/ opportunities, project design, options appraisal, understanding overall value, implementation, verification and maintenance. 


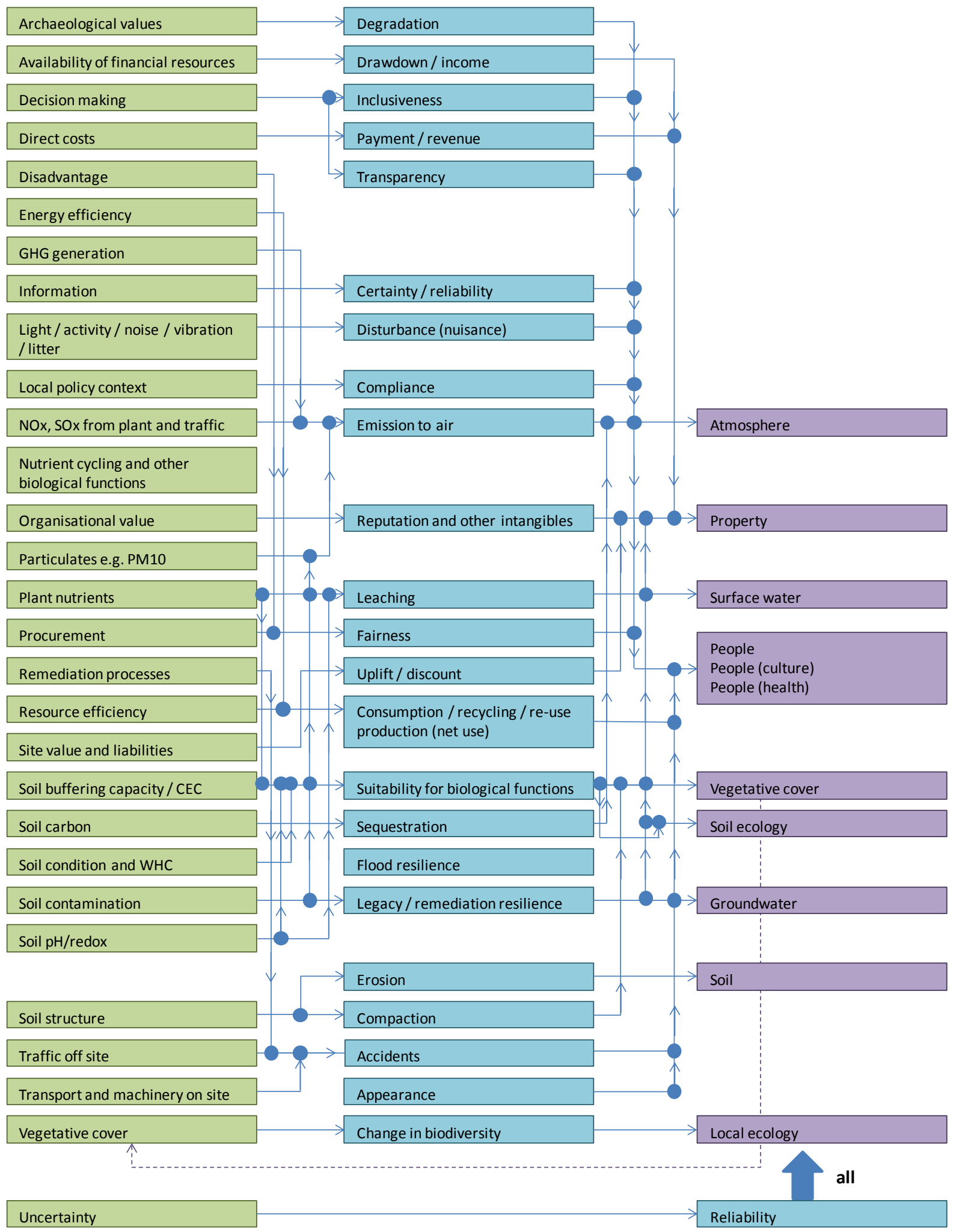

Figure 9: Example of a Project Sustainability Model Using a Network Diagram to Represent Linkages 
The importance of a conceptual site model of sustainability for overall value is intended to be twofold. Firstly, its use during design stages of the project assists the identification of opportunities for extending project services (as explained above). Secondly, it can be used to assist the estimation of overall value. Its individual linkages can be explicitly assigned to the different components of overall value providing a structure for the monetisation of direct financial and economically tangible wider effects, and identifying wider effects that stakeholders cannot agree as monetisable.

\section{Concluding remarks}

Soft re use of brownfield sites, for instance for amenity or biomass crops or other uses where the soil remains unsealed and functional can provide a wide range of valuable services both in urban and more rural contexts. However, their overall value can be difficult to monetise in a way that is accepted by all stakeholders. There is a need for broader value determination than simple forms of CBA to show clearly the added value of soft uses

Considering the specific services delivered by a restoration project may be a good starting point for the understanding of the creation of value in an overall sense. In this context a 'project service' is the delivery of specific benefits to beneficiaries who may be investors in the project, and also (more widely) nature, communities or society. Services are specific outcomes of a project design process. Services are delivered through interventions, i.e. the implementation of restoration processes and/or the subsequent maintenance of specific reuses. The sustainability of a project is therefore a function of these services and their wider effects. The concept of 'project services' proposed overlaps the concept of ecosystem services, but is not precisely aligned with it. Project services may be delivered by ecosystems, but also by non-ecosystem processes or they may be consequential economic benefits.

The HOMBRE project has developed the Brownfield Opportunity Matrix (BOM) to identify opportunities for value creation from services provided by the soft re-use of brownfield sites. The matrix allows for the identification of multiple project services from restoration initiatives at different stages in a project design and discussion process.

Investment decisions by Private and Public Sector investors are often made on the basis of cost benefit assessments. However, these assessments can be unreliable as wider benefits (and impacts) are difficult to monetise in a way that is always acceptable to all stakeholders in a restoration project. The overall value of a project can be broken down into three components: the direct financial balance of costs and benefits, economically tangible costs and benefits (i.e. which stakeholders agree are monetisable) and economically intangible costs and benefits (i.e. which stakeholders cannot agree as monetisable). Using a combination of cost-benefit analysis for direct financial and economically tangible costs and benefits, with an alternative aggregation index for intangibles which is not based on monetary values may be a means of providing an agreed expression of the overall value of a restoration project. Individual stakeholders can then complete a cost-benefit analysis considering these intangibles using precedents such as goodwill for their own internal 
decision making purposes, while the combined assessment remains the shared expression of overall value.

Conceptual models of sustainability can support a shared understanding which can provide a basis for evaluating overall value. HOMBRE suggests the use of explicit 'sustainability linkages' to build conceptual models of sustainability which can then be developed iteratively through the project design and implementation process. A CSM integrates both the desired outcomes of designed in project services as well as their wider impacts (good or bad). Individual linkages then can be mapped precisely to components of overall value and so provide a structure for determining direct financial returns, and economically tangible and intangible values.

\section{Acknowledgments}

The work described in this publication was supported by the European Community's Seventh Framework Programme through the grant to the budget of the HOMBRE Project, Grant Agreement Number 265097, along with addional inputs from r3 environmental technology Itd, University of Brighton and Vertase-FLI

This work benefited from constructive review and criticism from the HOMBRE Project consortium as a whole and the Project Advisory Group, as well as a number of external reviewers and commentators: Kieron Doick, Forest Research, UK; Stephen Broekx, VITO, Belgium; Erika Rizzo, University Ca' Foscari Venice, Italy; and Andy Cundy, University of Brighton, UK.

\section{References}

Ackermann, F. (2008) Critique of Cost-Benefit Analysis, and Alternative Approaches to Decision-Making. A report to Friends of the Earth England, Wales and Northern Ireland. January 2008, www.foe.co.uk/resource/reports/policy appraisal.pdf Accessed July 2015.

Adelaja, S., Shaw, J., Beye, W. and McKeowna, J.D.C. (2010) Renewable energy potential on brownfield sites: A case study of Michigan. Energy Policy 38 (11) 7021-7030

Ahmad, M., Rajapaksha, A. U., Lim, J. E., Zhang, M., Bolan, N., Mohan, D. Vithanage, M., Lee, S. S. and Ok, Y. S. (2014). Biochar as a sorbent for contaminant management in soil and water: a review. Chemosphere, 99, 19-33.

Alcock, I., White, M. P., Wheeler, B. W., Fleming, L. E., and Depledge, M. H. (2014). Longitudinal effects on mental health of moving to greener and less green urban areas. Environmental Science and Technology, 48(2), 1247-1255.

Atkinson, G., Doick, K.J., Burningham, K., and France, C. (2014) Brownfield regeneration to green space: Delivery of project objectives for social and environmental gain Urban forestry and urban greening. 13 586-594. 
Atkinson, G., and Mourato, S. (2008). Environmental cost-benefit analysis. Annual review of Environment and Resources, 33, 317-344.

Bambra, C., Robertson, S., Kasim, A., Smith, J., Cairns-Nagi, J. M., Copeland, A., Finlay, N.and Johnson, K. (2014). Healthy land? An examination of the area-level association between brownfield land and morbidity and mortality in England. Environment and Planning A., 46 (2), 433-454.

Bardos, R. P. (2008a). Report of the NICOLE / SAGTA Workshop: Sustainable Remediation 3rd March 2008, London, UK, Land Contamination and Reclamation,16 (4), 381-403.

Bardos, R.P. (2008b). Report of the NICOLE Workshop: Environmental Decision Support Systems 9-10 October 2008 Madrid, Spain, NICOLE Secretariat, Deltares / TNO, Apeldoorn, the Netherlands.http://www.nicole.org/publications/library.asp?listing=1

Bardos, P. (2014) Progress in Sustainable Remediation. Remediation Journal Winter 2014 pp 23-32, DOI: 10.1002/rem.21412. www.wileyonlinelibrary.com

Bardos, R. P., Bone, B. D., Boyle, R., Ellis, D., Evans, F., Harries, N.and Smith, J.W.N. (2011). Applying Sustainable Development Principles to Contaminated Land Management Using the SuRF-UK Framework.Remediation Journal,21, (2), 77-100.

Bardos, R. P., Bone, B. D., Boyle, R., Evans, F., Harries, N., Howard, T. and Smith, J.W.N. (2016) The rationale for simple approaches for sustainability assessment and management in contaminated land practice. ibid

Bardos, P. and Menger, P. (2013) Conceptual Site or Project Models for Sustainability Assessment. ThS D3.3 Methods and tools for environmental footprint assessment. Proceedings Aquaconsoil 2013 Barcelona, Spain. April 2013. DOI: 10.13140/2.1.2336.5765

Bartke, S. (2011). Valuation of market uncertainties for contaminated land. International Journal of Strategic Property Management,15 (4) 356-378.

Bartke, S., and Schwarze, R. (2015). No perfect tools: Trade-offs of sustainability principles and user requirements in designing support tools for land-use decisions between greenfields and brownfields. Journal of Environmental Management, 153, 11-24.

BenDor, T.K., Metcalf, S.S. and Paich, M. (2011). The Dynamics of brownfield Redevelopment. Sustainability,3, 914-936. DOI:10.3390/su3060914.

Beinat, E., van Drunen, M.A., Janssen, R., Nijboer, M.H., Loolenbrander, J. G. M., Okx, J.P., Schutte, A.R. (1998) The REC Decision Support Sustem for comparing soil remediation alternatives. Phase 2: A methodology based on Risk reduction, Environmental merit and Costs. NOBIS-report 95-1-03, The Netherlands. http://soilpedia.nl/Bikiwiki\%20documenten/NOBIS/Risicoreductie,\%20Milieuverdienste\%20 en\%20Kosten\%20(RMK)\%20-\%2095-1-03/95-1-03\%20rap2.pdfAccessed July 2015 
Benedict, M. A., and McMahon, E. T. (2006). Green infrastructure. Renewable Resources Journal,20(3), 12-17.

Beumer, V., Bardos, P., Menger, P., Bingham, J., Maring, L., Moinier, S., Rizzo, E., Stephenson, I. and Storey, P. (2014). D 5.2: 'Decision support system on soft reuses'. HOMBRE Deliverable 5.2 . http://www.zerobrownfields.eu/HombreTrainingGallery/HOMBRE D5.2 final.pdf Accessed July 2015

Bleicher, A. and Groß, M.S (2010): Sustainability assessment and the revitalization of contaminated sites: operationalizing sustainable development for local problems, International Journal of Sustainable Development \& World Ecology 17(1), 57-66.

Bolund, P., and Hunhammar, S. (1999). Ecosystem services in urban areas. Ecological Economics, 29 (2), 293-301.

Brouwer, R. and van Ek, R. (2004) Integrated ecological, economic and social impact assessment of alternative flood control policies in the Netherlands.Ecological Economics,50, $1-21$.

CABE - Commission for Architecture and the Built Environment (2005) Start with the park. Creating sustainable urban green spaces in areas of housing growth and renewal. CABE, London, UK. ISBN: 1-84633-000-9

http://webarchive.nationalarchives.gov.uk/20110118095356/http:/www.cabe.org.uk/files/s tart-with-the-park.pdf Accessed November 2015

CABERNET (2006). Sustainable brownfield Regeneration: CABERNET Network Report. Eds: Ferber, U., Grimski, D., Millar, K. and Nathanail, P. University of Nottingham, Nottingham. ISBN 0-9547474-5-3.

Caeiro, S., Ramos, T.B. and Huisingh, D. (2010) A conceptual model for the development of household sustainable consumption indicators. The 14th European Roundtable on Sustainable Production and Consumption (ERSCP); The 6th Environmental Management for Sustainable Universities (EMSU). http://repository.tudelft.nl/assets/uuid:95b232e7-87be4124-b97f-409c47e07c00/137 Caeiro.pdf. Accessed July 2015

Cappuyns, V. and Kessen, B. (2012) Evaluation of the environmental impact of Brownfield remediation options: comparison of two life cycle assessment-based evaluation tools. Environmental Technology 33 (21) 2447-2459

Cellini, S.R. and Kee, J.E. (2010). Cost-Effectiveness and Cost-Benefit Analysis, in (Eds. Wholey, J. S., Hatry, H. P. and Newcomer, K. E.) Handbook of Practical Program Evaluation, 3rd Edition,Wiley, pp 493-530. ISBN: 978-0-470-52247-9.

Chiesura, A. (2004). The role of urban parks for the sustainable city. Landscape and Urban Planning, 68 (1), 129-138. 
Chilton, K, Schwarz, P. and Godwin, K. (2009) Verifying the Social, Environmental, and Economic Promise of brownfield Programs. Final Report. US EPA brownfields Training, Research, and Technical assistant Grants and Cooperative Agreements Program, BFRES-0402. www.epa.gov/brownfields/trta_k6/trta report 2009.pdf Accessed July 2015

CL:AIRE. (2006). The Role of the UK Development Industry in brownfield Regeneration. subr:im Bulletin SUB 1. Contaminated Land: Applications in Real Environments (CL:AIRE), London, UK. www.claire.co.uk Accessed July 2015

CL:AIRE. (2007a). Uncovering the True Impacts of Remediation. subr:im Bulletin SUB 2.CL:AIRE, London, UK. www.claire.co.uk Accessed July 2015

CL:AIRE. (2007b). Measuring Sustainability: What's in a Number? subr:im Bulletin SUB 4.CL:AIRE, London, UK. www.claire.co.uk Accessed July 2015

CL:AIRE, (2011) The SuRF-UK Indicator Set for Sustainable Remediation Assessment London, UK. ISBN 978-1-905046-1292-5 www.claire.co.uk/surfuk Accessed July 2015

Commonwealth of Australia (2006) Introduction to Cost-Benefit Analysis and Alternative Evaluation Methodologies January 2006 FINANCIAL MANAGEMENT REFERENCE MATERIAL NO. 5 ISBN 1921182024 http://www.finance.gov.au/publications/financecirculars/2006/docs/Intro to CB analysis.pdf

Cowan, R., Hill, D., Campbell, K., Chapman, D., Dodd, P., Lawlor, D., Lorimer, S., Nowell, H. (2005). Start with the Park: Creating sustainable urban green spaces in areas of housing growth and renewal.

http://webarchive.nationalarchives.gov.uk/20110118095356/http:/www.cabe.org.uk/files/s tart-with-the-park.pdf Accessed July 2015

Cundy, A. B., Bardos, R. P., Church, A., Puschenreiter, M., Friesl-Hanl, W., Müller, I., Müller, Neu, S., Mench, M., Witters, N., and Vangronsveld, J. (2013). Developing principles of sustainability and stakeholder engagement for 'gentle' remediation approaches: the European context. Journal of Environmental Management, 129, 283-291.

DCLG - Department for Communities and Local Government (2011) The community infrastructure levy. An overview. DCLG, London, UK.

www.gov.uk/government/uploads/system/uploads/attachment data/file/6313/1897278.p df Accessed July 2015

Defra - Department of Environment Food and Rural Affairs (2012) Options for a Strategy for Economic Assessment of the Benefits of Contaminated Land Remediations. Final report. AMEC Environment and Infrastructure UK Limited. August 2012, Defra, London, UK. http://randd.defra.gov.uk/Default.aspx?Menu=MenuandModule=MoreandLocation=Nonea ndCompleted=0andProject|D=17468 Accessed July 2015 
Döberl,G., Ortmann, M. and Frühwirth, W. (2013) Introducing a goal-oriented sustainability assessment method to support decision making in contaminated site management. Env, Sci. Policy $25207-217$

Doick, K. J. and Hutchings, T. (2013). Air temperature regulation by urban trees and green infrastructure. Forestry Commission Research Note, February 2013. ISBN: 978-0-85538-8782

Doick K.J., Sellers G., Castan Broto V., Silverthorne T.; (2009) Understanding success in the context of Brownfield greening projects: the requirement for outcome evaluation in urban green space success assessment, Urban forestry and urban greening. 8 (3) 163-178.

DVRPC - Delaware Valley Regional Planning Commission (2008). Reclaiming brownfields. http://www.dvrpc.org/reports/09002.pdf Accessed July 2015

EC (2012). Guidelines on best practice to limit, mitigate or compensate soil sealing, Commission Staff Working Document, Brussels, 12.4.2012,SWD(2012) 101 final http://ec.europa.eu/environment/soil/pdf/soil sealing guidelines en.pdf.

ELD Initiative (2015). The value of land: Prosperous lands and positive rewards through sustainable land management. Available from www.eld-initiative.org.

Engel, H. (1988). Maximilianpark Hamm. Ein Park auf Kohle. Herausgeber Maximilianpark $\mathrm{GmbH}$.

Ferber, U., Grimski, D., Millar, K. and Nathanail, P. (2006). Sustainable brownfield Regeneration: CABERNET Network Report. University of Nottingham. ISBN 0-95474745-3

Ferber, U. Jackson, J. B. and Starzewsk-Sikorska, A. (2011). Circular flow land use management in: proceedings Real corp 2011, 18-20 may 2011, Essen, Germany.

Forest Research (2010) Benefits of green infrastructure. Report by Forest Research. Defra Contract number WC0807, Forest Research. Forest Research, Farnham. http://www.forestry.gov.uk/pdf/urgp benefits of green infrastructure.pdf/\$FILE/urgp be nefits of green infrastructure.pdf Accessed November 2015

Greenspace Alliance, Delaware Valley Regional Planning Commission. (2010). The Economic Value of Protected Open Space in Southeastern Pennsylvania, November 16, 2010. www.dvrpc.org/openspace/value Accessed July 2015

Haase, D. (2008) Urban Ecology of Shrinking Cities: An Unrecognized Opportunity? Nature and Culture 3 (1) 1-8

Haase D., Schwarz N., Strohbach M., Kroll F., Seppelt R. (2012). Synergies, trade-offs and losses of ecosystem services in urban regions: an integral multiscale framework applied to the Leipzig-Halle region, Germany. Ecology and Society,17 (3), 22. 
Handley, J.F. (1996). The Post Industrial Landscape - A resource for the community, a resource for the nation? A Groundwork Status Report. The Groundwork Foundation, 85-87 Cornwall Street, Birmingham B3 3BY, England.

Harbottle, M.J., A. Al-Tabbaa, C.W. Evans (2008)a Sustainability of land remediation, Part 1: overall analysis, Proceedings of the Institution of Civil Engineers Geotechnical Engineering 161, April 2008 Issue GE2: 75-92,

Harbottle, M.J., A. Al-Tabbaa, A., C.W. Evans (2008)b Sustainability of land remediation, Part 2: impact assessment, Proceedings of the Institution of Civil Engineers Geotechnical Engineering 161, June 2008 Issue GE3: 117-127.

Hardi, P. and Zdan, T.J. (1997).Assessing sustainable development International Institute for Sustainable Development, 161 Portage Avenue East - 6th Floor, Winnipeg,Manitoba, R3B OY4, Canada, ISBN 1-895536-07-3, http://www.iisd.org/pdf/bellagio.pdf

HM Treasury (2011) The Green Book. Appraisal and Evaluation in Central Government. Treasury Guidance, TSO, London. www.gov.uk/government/uploads/system/uploads/attachment data/file/220541/green b ook complete.pdf Accessed August 2015

Holland, K., Karnis, S., Kasner, D. A., Butler, P. B., Hadley, P. W., Nathanail, P., Ryan, J., Smith, L. M.and Wice, R. (2013). Integrating Remediation and Reuse to Achieve Whole-System Sustainability Benefits. Remediation Journal, 23(2), 5-17.

HOMBRE Consortium (2014) HOMBRE's Role in brownfields Management and Avoidance. Project brochure. FP7 Project grant agreement no. 265097. Deltares, Delft, The Netherlands. www.zerobrownfields.eu/quicklinks/HOMBRE Broschure 2014 FINAL.pdf Accessed July 2015

International Standards Organisation - ISO (2015) ISO/DIS 18504 Soil quality -- Guidance on sustainable remediation

http://www.iso.org/iso/home/store/catalogue tc/catalogue detail.htm?csnumber=62688

Accessed November 2015

Lee, N.G. and Coffin, S.L. (2005) Modeling the relationship among brownfields, property values, and community revitalization. Housing Policy Debate, Volume 16, Issue 2

Ling, C., Handley, J. and Rodwell, J. (2003) Multifunctionality and scale in post-industrial land regeneration. Pp27-34 in Land Reclamation Proceedings of the 7th International Conference, Runcorn, UK, 13-16 May 2003 . (Eds Moore, H.M., Fox, H.R. and Elliott, S.) A A Balkema Publishers ISBN 9058095622

Lord, R. A., Atkinson, J., Lane, A., Scurlock, J., and Street, G. (2008). Biomass, remediation, restoration (BioReGen Life Project): Reusing brownfield sites for renewable energy crops. GeoCongress, 177, 52. 
Luederitz, C. Brink, E., Gralla, F., Hermelingmeier, V., Meyerd, M., Niven, L. Panzerc, L., Partelow, S., Rauf, A.-L. Sasakib, R., Absong, D.J., Lang, D.J., Wamsler, C., von Wehrden, H. (2015) A review of urban ecosystem services: six key challenges for future research. Ecosystem Services 14 98-112

Mathey,J., Rößle, S., Banse, J., Lehmann, I. and Bräuer, A. (2015) Brownfields As an Element of Green Infrastructure for Implementing Ecosystem Services into Urban Areas. Journal of Urban Planning and Development Volume 141, Issue 3 http://dx.doi.org/10.1061/(ASCE)UP.1943-5444.0000275

Menger, P. Bardos, P., Ferber, U., Neonato, F., Maring, L., Beumer, V., Track, T. and Wendler, K. (2013). D 5.1: 'Valuation approach for services from restoration of brownfields for soft re-use on a permanent or interim basis'. HOMBRE Deliverable 5.1. http://www.zerobrownfields.eu/HombreTrainingGallery/HomePage/HOMBRE D5.1 final S ervices SoftReUse.pdf Accessed July 2015

Morrison, S., Fordyce, F. M. and Marian Scott, E. (2014) An initial assessment of spatial relationships between respiratory cases, soil metal content, air quality and deprivation indicators in Glasgow, Scotland, UK: relevance to the environmental justice agenda. Environmental Geochemistry and Health, 36, 319-332

Nathanail, C. P. and Bardos, R.P. (2004). Reclamation of Contaminated Land Wiley and Sons. ISBN $0471985600 \quad$ http://www.wileyeurope.com/WileyCDA/WileyTitle/productCd0471985619.html.

Natural England (2009). Green Infrastructure Guidance. http://publications.naturalengland.org.uk/publication/35033

NICOLE (2011). Environmental liability transfer in Europe: Divestment of contaminated land for brownfield restoration. Report of the brownfield Working Group May 2011. NICOLE secretariat, Appeldoorn, The Netherlands. www.nicole.org

Nowak, D.J., Crane, D.E. and Stevens, J.C. (2006) Air pollution removal by urban trees and shrubs in the United States. Urban Forestry and Urban Greening, 4 115-123

Paull, E. (2008) The environmental and economic impacts of Brownfields redevelopment. Working Draft for Distribution. July 2008. Northeast-Midwest Institute, Washington DC, USA. $\quad$ http://www.nemw.org/wp-content/uploads/2015/06/2008-Environ-Econ-ImpactsBrownfield-Redev.pdf Accessed November 2015

Pediaditi, K., Wehrmeyer, W., and Chenoweth, J. (2005). Monitoring the Sustainability of brownfield Redevelopment Projects. The Redevelopment Assessment Framework (RAF), Contaminated Land and Reclamation, 13(2), 173-183

Pizzol, L., Zabeo, A., Klus, P., Giubilato, E., Critto, A., Frant, B., Martin, S., Kunc, J., Osman, R. and Bartke, S. (2016) Timbre Brownfield Prioritization Tool to support effective brownfield Regeneration. Journal of Environmental Management 166 178-192 
Plant, R., Chong, J., Lederwasch, A., Prior, J., and Asker, S. (2015) in press. Value-based land remediation: improved decision-making for contaminated land. Adelaide: CRC for Contamination Assessment and Remediation of the Environment.

RESCUE Consortium (2005) Best Practice Guidance for Sustainable brownfield Regeneration. May 2005. Land Quality Press, a Division of Land Quality Management Ltd. ISBN 0-9547474$0-2$

REVIT Consortium (2007). Working towards more effective and sustainable brownfield revitalisation policies. Ensuring sustainability in brownfield revitalisation.http://www.revitnweurope.org/download/Ensuring_Susatinability_in_brownfield_Revitalisation.pdf.

Accessed January 2013.

Riley, R., Robinson, C. and Davison, S. (2011) Skills and economic performance: The impact of intangible assets on UK productivity. Evidence Report 39. October 2011. UK Commission for Employment and Skills. ISBN 978-1-906597-73-3. www.gov.uk/government/uploads/system/uploads/attachment data/file/303075/evidence -report-39-skills-and-economic-performance.pdf Accessed July 2015

Rizzo, E., Bardos, P., Pizzol, L., Critto, A., Giubilato, E., Marcomin, A. et al. (in prep) Comparison of international approaches to sustainable remediation Submitted to Journal Environmental Management

Rodríguez, J. P., Beard, T. D. Jr., Bennett, E. M. Cumming, G. S. Cork, S. Agard, J. Dobson, A. P. and Peterson, G. D.(2006). Trade-offs across space, time, and ecosystem services. Ecology and Society11 (1), 28. URL: http://www.ecologyandsociety.org/vol11/iss1/art28.

Sarni, W. (2009). Greening brownfields: Remediation through sustainable development, 320 pp. McGraw-Hill Education - Europe.

Seeds Consrotium (2015) SEEDS Final Report. Interreg IVB Project. ISBN: 978-0-9930238-1-1 www.seeds-project.com/assets/doc/SEEDS-FINAL-REPORT-2015.pdf Accessed August 2015

Sinnett, D., Smith, N. and Burgess, S. (2015) Handbook on green infrastructure. Planning Design and Implementation. Edward Elgar Publishing Ltd. ISBN 9781783474004

Skelhorn, C., Lindley, S., and Levermore, G. (2014). The impact of vegetation types on air and surface temperatures in a temperate city: A fine scale assessment in Manchester, UK. Landscape and Urban Planning, 121, 129-140.

Syms, P.M. and Weber, B.R. (2003). International approaches to the valuation of land and property affected by contamination RICS Foundation, London, UK. August 2003. ISBN 184219-166-7. www.rics.org/site/download feed.aspx?filelD=2830andfileExtension=PDF. Accessed July 2015 
Tang, Y.-T. and Nathanail, C. P. (2012) Sticks and Stones: The Impact of the Definitions of Brownfield in Policies on Socio-Economic Sustainability. Sustainability 4 (5), 840-862; doi:10.3390/su4050840

Taylor, J. R., and Lovell, S. T. (2012). Mapping public and private spaces of urban agriculture in Chicago through the analysis of high-resolution aerial images in Google Earth. Landscape and Urban Planning, 108(1), 57-70.

TEEB - The Economics of Ecosystems and Biodiversity (2011).A The Economics of Ecosystems and Biodiversity in National and International Policy Making. Edited by Patrick ten Brink. Earthscan, London and Washington.

TEEB - The Economics of Ecosystems and Biodiversity (2011)B. TEEB Manual for Cities: Ecosystem Services in Urban Management. www.teebweb.org Accessed July 2015

Thornton, G., Franz, M., Edwards, D., Pahlen, G., and Nathanail, P. (2007). The challenge of sustainability: incentives for brownfield restoration in Europe. Environmental Science and Policy,10, $116-134$.

Todorov, V.I. and Marinova, D. (2009) Models of sustainability. 18th World IMACS / MODSIM Congress, Cairns, Australia 13-17 July 2009. www.mssanz.org.au/modsim09/D2/todorov D2a.pdf Accessed July 2015

US EPA - Environmental Protection Agency (2010). From Brown to Green: Restoring Ecosystems on Former brownfields. EPA 560-F-10-210 http://www.epa.gov/brownfields/success/ecological restoration ss 071310.pdf Accessed July 2015

VALUE Project Consortium (2012). VALUE Project Final report. http://www.valuelandscapes.eu/cmsFiles/VALUE-Project-Final-Report.pdf Accessed July 2015

Van Arkel, L. (2012) Adaptive brownfield management. PhD Thesis. Erasmus University Rotterdam 30 November 2012. http://thesis.eur.nl/pub/17868/Adaptive-brownfieldmanagement-Levinia-van-Arkel-november-2012.pdf. Accessed November 2015

Van der Meulen, V., Verspecht, A., Vermeirb, B., Van Huylenbroeck, G. and Gellynck, X. (2011). The use of economic valuation to create public support for green infrastructure investments in urban areas. Landscape and Urban Planning,103,198- 206.

World Resources Institute (2003) Millennium Ecosystem Assessment Ecosystems and Human Well-being A Report of the Conceptual Framework Working Group of the Millennium Ecosystem Assessment. Island Press, Washington DC, USA. http://pdf.wri.org/ecosystems human wellbeing.pdf, Accessed August 2015 